\title{
0 tempo da fronteira retorno à controvérsia sobre o tempo histórico da frente de expansão e da frente pioneira
}

\author{
JOSÉ DE SOUZA MARTINS
}

RESUMO: O tema da fronteira é um tema recorrente na literatura brasileira de Ciências Sociais. Apesar das tentativas de alguns antropólogos de importar as idéias que F. Turner desenvolveu para explicar o deslocamento da fronteira nos Estados Unidos, e que tratam da influência da fronteira na formação do caráter nacional americano, essas idéias, a rigor, não se aplicam no caso brasileiro. Geógrafos e antropólogos, entre os anos 30 e 50, realizaram pesquisas de campo que se tornaram essenciais para uma concepção sociológica da fronteira enraizada no que há de historicamente singular e sociologicamente relevante no caso brasileiro. É a partir dessas referências que o autor formula a sua tese de que a fronteira é, simultaneamente, lugar da alteridade e expressão da contemporaneidade dos tempos históricos. A unidade do diverso, pressuposto metodológico da dialética, encontra aí o lugar mais adequado e mais rico para a investigação científica.

om razão observa Alistair Hennessy que as sociedades latino-americanas ainda estão no estágio da fronteira (Hennessy, 1978, p. 3). Ainda se encontram naquele estágio de sua história em que as relações sociais e políticas estão, de certo modo, marcadas pelo movimento de expansão demográfica sobre terras "não ocupadas" ou "insuficientemente" ocupadas. Na América Latina, a última grande fronteira é a Amazônia, em particular a Amazônia brasileira, como assinalou Foweraker (1982, p. 11), ou "última fronteira terrestre que desafia a tecnologia moderna",
UNITERMOS:

fronteira, tempo histórico, tempo de fronteira, movimentos sociais, peonagem, frente de expansão, frente pioneira.

Exposição de abertura da Conferência The Frontier in Question, promovida pelo Departamento de História da Universidade de Essex, Colchester, Reino Unido, 21 a 23 de abril de 1995.

Professor do Departamento de Sociologia da FFLCH-USP. Fellow de Trinity Hall e Professor Titular da Cátedra Simón Bolivar daUniversidade de Cambridge no ano acadêmico de 1993/94 
como observou Posey (1982, p. 89). Desde o início da Conquista foi ela objeto de diferentes movimentos de penetração: na caça e escravização do índio, na busca e coleta das plantas conhecidas como "drogas do sertão", na coleta do látex e da castanha. A partir do golpe de Estado de 1964 e do estabelecimento da ditadura militar, a Amazônia transformou-se num imenso cenário de ocupação territorial massiva, violenta e rápida, processo que continuou, ainda que atenuado, com a reinstauração do regime político civil e democrático em 1985.

A história do recente deslocamento da fronteira é uma história de destruição. Mas, é também uma história de resistência, de revolta, de protesto, de sonho e de esperança. A nossa consciência de homens comuns e também a nossa consciência de intelectuais e especialistas se move no território dessa contradição. Como tantos outros pesquisadores, também fui e tenho sido testemunha desse movimento, que acompanhei pessoal e diretamente num ritmo impróprio para a pesquisa sociológica moderna, o ritmo da paciência, da observação demorada e reiterada. Meu trabalho certamente diverge dos trabalhos costumeiros sobre a fronteira, do pesquisador com prazo e pressa, que precisa concluir sua tarefa nos limites de uma cronologia apertada. E que, muitas vezes, deve limitar sua pesquisa de campo a lugares acessíveis, pacíficos e pouco representativos da conturbada realidade da fronteira, que já não são propriamente fronteira. Ou que, sobretudo, pode fazê-la somente muito depois das ocorrências mais características e violentas da vida social na fronteira, quando a rigor a população local já não se encontra na situação de fronteira ${ }^{1}$.

A história contemporânea da fronteira, no Brasil, é a história das lutas étnicas e sociais. Entre 1968 e 1987, diferentes tribos indígenas da Amazônia sofreram pelo menos 92 ataques organizados, principalmente, por grandes proprietários de terra, com a participação de seus pistoleiros, usando armas de fogo. Por seu lado, diferentes tribos indígenas realizaram pelo menos 165 ataques a grandes fazendas e a alguns povoados, entre 1968 e 1990, usando muitas vezes armas primitivas como bordunas e arco-e-flecha. Houve ocasiões em que diferentes tribos fizeram ataques em diferentes lugares no mesmo dia. Nestes últimos trinta anos, diferentes facções da tribo Kayapó lançaram continuados ataques às fazendas de sua região, inicialmente para rechaçar os civilizados e depois de pacificados para impedir que continuassem invadindo seu território. Em 1984, os Kayapó-Txukahamãe sustentaram uma verdadeira guerra de 42 dias contra as fazendas e o governo militar, que culminou com o fechamento definitivo de extenso trecho da rodovia BR-080, maliciosamente aberta através de seu território para possibilitar futura invasão das terras por grandes fazendeiros. Nessas lutas, houve mortos de ambos os lados, verdadeiros massacres.

Não só os índios da fronteira foram envolvidos na luta violenta pela terra. Também os camponeses da região, moradores antigos ou recentemente migrados, foram alcançados pela violência dos grandes proprietários de terra, pelos assassinatos, pelas expulsões, pela destruição de 
casas e povoados. Entre 1964 e 1985, quase seiscentos camponeses foram assassinados em conflitos na região amazônica, por ordem de proprietários que disputavam com eles o direito à terra.

O que há de sociologicamente mais relevante para caracterizar e definir a fronteira no Brasil é, justamente, a situação de conflito social ${ }^{2}$. E esse é, certamente, o aspecto mais neglicenciado entre os pesquisadores que têm tentado conceituá-la. Na minha interpretação, nesse conflito, a fronteira é essencialmente o lugar da alteridade. É isso o que faz dela uma realidade singular. À primeira vista é o lugar do encontro dos que por diferentes razões são diferentes entre si, como os índios de um lado e os civilizados de outro; como os grandes proprietários de terra, de um lado, e os camponeses pobres, de outro. Mas, o conflito faz com que a fronteira seja essencialmente, a um só tempo, um lugar de descoberta do outro e de desencontro ${ }^{3}$. Não só o desencontro e o conflito decorrentes das diferentes concepções de vida e visões de mundo de cada um desses grupos humanos. O desencontro na fronteira é o desencontro de temporalidades históricas, pois cada um desses grupos está situado diversamente no tempo da História. Por isso, a fronteira tem sido cenário de encontros extremamente similares aos de Colombo com os índios da América: as narrativas das testemunhas de hoje, cinco séculos depois, nos falam das mesmas recíprocas visões e concepções do outro ${ }^{4}$.

A fronteira só deixa de existir quando o conflito desaparece, quando os tempos se fundem, quando a alteridade original e mortal dá lugar à alteridade política, quando o outro se torna a parte antagônica do nós. Quando a História passa a ser a nossa História, a História da nossa diversidade e pluralidade, e nós já não somos nós mesmos porque somos antropofagicamente nós e o outro que devoramos e nos devorou 5 .

\section{Frente de expansão e frente pioneira: a diversidade histórica da fronteira}

Os estudiosos do tema da fronteira no Brasil, quando examinam a literatura pertinente, deparam-se com duas concepções de referência, através das quais os pesquisadores tem procurado dar um nome específico a essa realidade singular que é objeto de sua investigação. Os geógrafos, desde os anos 40, importaram a designação de zona pioneira para nomeá-la, outras vezes referindo-se a ela como frente pioneira ${ }^{6}$.

Os antropólogos, por seu lado, sobretudo a partir dos anos cinqüenta, definiram essas frentes de deslocamento da população civilizada e das atividades econômicas de algum modo reguladas pelo mercado, como frentes de expansão. Como sugere Darcy Ribeiro, autor do mais importante estudo sobre essas frentes, elas constituem as fronteiras da civilização. Se tomarmos como referência a emblemática frente de expansão da região amazônica, temos nela um primeiro contraste com a frente pioneira dos geógrafos: "Aqui a terra em si mesma não tem qualquer valor... (...) Não se cogita, por isto, de assegurar a posse legal das terras... (...) E este domínio não assume, senão acidentalmente

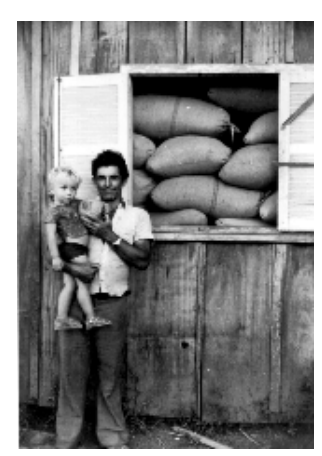

Colono gaúcho da frente pioneira e sua safra de arroz no Projeto Canarana, Mato Grosso (1979).

Todas as fotos são de $\mathrm{J}$. S. Martins. 
a forma de propriedade fundiária" (cf. Ribeiro, 1977, p. 25). A designação de frentes de expansão, que o próprio Ribeiro havia formulado, tornou-se de uso corrente, até mesmo entre antropólogos, sociólogos e historiadores que não estavam trabalhando propriamente com situações de fronteira da civilização. Ela expressa a concepção de ocupação do espaço de quem tem como referência as populações indígenas, enquanto a concepção de frente pioneira não leva em conta os índios e tem como referência o empresário, o fazendeiro, o comerciante e o pequeno agricultor moderno e empreendedor.

Portanto, o que temos, nas duas definições, é, antes de tudo, modos de ver a fronteira, diferentes entre si porque são diferentes, nos dois casos, os lugares sociais a partir dos quais a realidade é observada: o do chamado pioneiro empreendedor e o do antropólogo preocupado com o impacto da expansão branca sobre as populações indígenas ${ }^{7}$. Esse antropólogo não vê a frente de expansão como sendo apenas o deslocamento de agricultores empreendedores, comerciantes, cidades, instituições políticas e jurídicas. Ele inclui nessa definição também as populações pobres, rotineiras, não-indígenas ou mestiças, como os garimpeiros, os vaqueiros, os seringueiros, castanheiros, pequenos agricultores que praticam uma agricultura de roça antiquada e no limite do mercado.

Quando difundiram no Brasil a expressão "frente pioneira", os geógrafos mal viam os índios no cenário construído por seu olhar dirigido. Monbeig define os índios alcançados (e massacrados) pela frente pioneira no oeste de São Paulo, como precursores dessa mesma frente, como se estivessem ali transitoriamente, à espera da civilização que acabaria com eles. A ênfase original de suas análises estava no reconhecimento das mudanças radicais na paisagem pela construção das ferrovias, das cidades, pela difusão da agricultura comercial em grande escala, como o café e o algodão.

Não há, à primeira vista, nessas concepções de frente de expansão e de frente pioneira, a intenção de supor uma realidade específica e substantiva. Por isso mesmo, não são propriamente conceitos, mas, apenas designações através das quais os pesquisadores na verdade reconhecem que estão em face dos diferentes modos como os civilizados se expandem territorialmente. Mais do que momentos e modalidades de ocupação do espaço, referem-se a modos

Nascimento de cidade na frente pioneira: Canarana, Mato Grosso (1979).

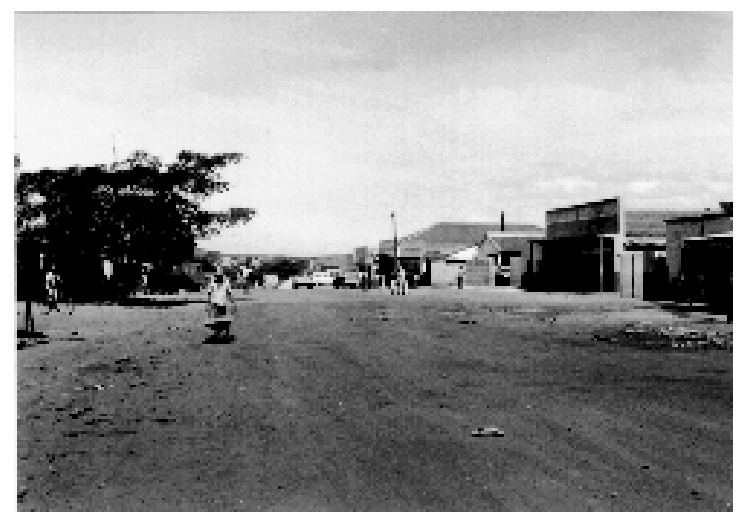


de ser e de viver no espaço novo. Entendo que essas distintas e, de certo modo, desencontradas perspectivas, levam a ver diferentes coisas porque são expressões diferentes da mesma coisa.

A concepção de frente pioneira compreende implicitamente a idéia de que na fronteira se cria o novo, nova sociabilidade, fundada no mercado e na contratualidade das relações sociais. No fundo, portanto, a frente pioneira é mais do que o deslocamento da população sobre territórios novos, mais do que supunham os que empregaram essa concepção no Brasil. A frente pioneira é também a situação espacial e social que convida ou induz à modernização, à formulação de novas concepções de vida, à mudança social. Ela constitui o ambiente oposto ao das regiões antigas, esvaziadas de população, rotineiras, tradicionalistas e mortas ${ }^{8}$.

Entretanto, as idéias subjacentes às duas concepções, de frente de expansão e de frente pioneira, sugerem que, apesar das aparências em contrário, elas se referem a realidades sociais substantivas, modos singulares de organização da vida social, de definição dos valores e das orientações sociais. Realidades substantivas que não foram definidas por aqueles que as empregaram. Os antropólogos, quando falam de frente de expansão, fazemno basicamente para poupar palavras na definição daquilo com que se defronta o índio. Não estão dizendo nada de específico e definido. Estão dizendo que sobre os territórios tribais se move a fronteira populacional e cultural dos brancos. A noção de frente de expansão, nesse contexto, apóia-se essencialmente em subentendidos. Esses subentendidos afloraram nas duas últimas décadas, nos trabalhos dos autores que fizeram pesquisa na região amazônica. Para uns, a frente de expansão aparece como sendo expansão da sociedade nacional; para outros como expansão do capitalismo 9 e para outros, até, como expansão do modo capitalista de produção. Originalmente, era expansão da fronteira da civilização. Obviamente, não há qualquer relacionamento imediato entre essas diferentes definições. Já a concepção de frente pioneira desaparece aos poucos, diluída na de frente de expansão, à medida sobretudo que a frente de expansão passa a ser entendida, predominantemente, como uma frente econômica.

A perda de substância antropológica da concepção de frente de expansão e sua redução aos aspectos meramente econômicos da vida na fronteira é certamente um fato a lamentar, pois empobreceu enormemente o estudo da expansão da fronteira no momento em que ele poderia ter sido antropologicamente mais rico. Antes dessa perda de substância, Roberto Cardoso de Oliveira pusera o tema da frente de expansão em termos mais adequados, mais ricos e mais promissores do que os que prevaleceriam depois. Em seus trabalhos, a frente de expansão se define pela situação de contato, isto é, pelo pressuposto metodológico da totalidade, como é próprio da tradição dialética (cf. Oliveira, 1964, p. 15-18). Aí, as relações interétnicas são relações de fricção interétnica, o equivalente lógico, mas não ontológico, como ele esclarece, da luta de classes (cf. Oliveira, 1967, p. 44). Embora Oliveira esteja 
Colônia do Projeto Humaitá, no Acre (1984). se referindo às relações entre índios e brancos, sua interpretação já é indicativa da impossibilidade de analisar a realidade dos protagonistas da fronteira de outro modo que não seja como momento de uma totalidade dialética e, portanto, momento de contradição e lugar de conflito ${ }^{10}$.

No meu modo de ver, o desencontro entre o que foi visto originalmente pelo geógrafo e o que foi visto pelo antropólogo, como disse antes, é produto de observações feitas em desiguais lugares sociais. No entanto, esses lugares sociais correspondem à própria realidade da fronteira. Eles viram a partir do vínculo que tinham com a fronteira na pesquisa científica. Viram, portanto, o que a fronteira lhes mostrava e o que estavam profissionalmente dispostos a ver. O desencontro de perspectivas é, nesse caso, essencialmente expressão da contraditória diversidade da fronteira, mais do que produto da diversidade de pontos de vista sobre a fronteira. Diversidade que é, sobretudo, diversidade de relações sociais marcadas por tempos históricos diversos e, ao mesmo tempo, contemporâneos.

A diferença inicial que os dois pontos de vista sugeriam era de que quando os geógrafos falavam de frente pioneira estavam falando de uma das faces da reprodução ampliada do capital: a sua reprodução extensiva e territorial, essencialmente mediante a conversão da terra em mercadoria ${ }^{11} \mathrm{e}$, portanto, em renda capitalizada, como indicava e indica a proliferação de companhias de terras e negócios imobiliários nas áreas de fronteira em que a expansão assume essa forma. Nesse sentido, estavam falando de uma das dimensões da reprodução capitalista do capital.

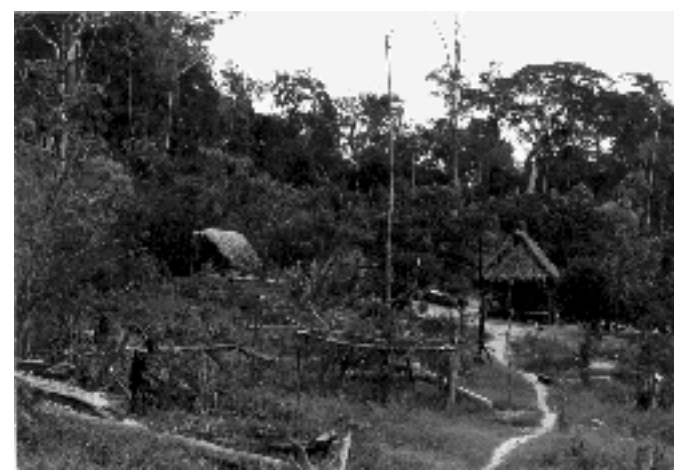

Quando os antropólogos falavam originalmente da frente de expansão, estavam falando de uma forma de expansão do capital que não pode ser qualificada como caracteristicamente capitalista. Essa expansão é essencialmente expansão de uma rede de trocas e de comércio, de que quase sempre o dinheiro está ausente, sendo mera referência nominal arbitrada por quem tem o poder pessoal e o controle dos recursos materiais na sua relação com os que explora, índios ou camponeses. O mercado opera, através dos comerciantes dos povoados, com critérios monopolísticos, mediados quase sempre por violentas relações de dominação pessoal, tanto na comercialização dos produtos quanto nas relações de trabalho (sendo aí característica a 
peonagem ou escravidão por dívida). Portanto, muito longe do que tanto Marx quando Weber poderiam definir como capitalista.

Neiva, em trabalho contemporâneo dessas formulações, assinalara que, no Brasil, era (e é) necessário distinguir, no interior das fronteiras políticas do país, a fronteira demográfica e a fronteira econômica, esta nem sempre coincidindo com aquela, geralmente aquém dela ${ }^{12}$. Isto é, a linha de povoamento avança antes da linha de efetiva ocupação econômica do território. Quando os geógrafos falam de frente pioneira, estão falando dessa fronteira econômica. Quando os antropólogos falam de frente de expansão, estão geralmente falando da fronteira demográfica. Isso nos põe, portanto, diante de uma primeira distinção essencial: entre a fronteira demográfica e a fronteira econômica há uma zona de ocupação pelos agentes da “civilização", que não são ainda os agentes característicos da produção capitalista, do moderno, da inovação, do racional, do urbano, das instituições políticas e jurídicas, etc. ${ }^{13}$.

É possível, assim, fazer uma primeira datação histórica: adiante da fronteira demográfica, da fronteira da "civilização", estão as populações indígenas, sobre cujos territórios avança a frente de expansão. Entre a fronteira demográfica e a fronteira econômica está a frente de expansão, isto é, a frente da população não incluída na fronteira econômica. Atrás da linha da fronteira econômica está a frente pioneira, dominada não só pelos agentes da civilização, mas, nela, pelos agentes da modernização, sobretudo econômica, agentes da economia capitalista (mais do que que simplesmente agentes da economia de mercado), da mentalidade inovadora, urbana e empreendedora. Digo que se trata de uma primeira datação histórica porque cada uma dessas faixas está ocupada por populações que, ou estão no limite da História, como é o caso das populações indígenas; ou estão inseridas diversamente na História, como é o caso dos não índios, sejam eles camponeses, peões ou empresários.

Cada uma dessas realidades tem o seu próprio tempo histórico, se considerarmos que a referência à inserção ou não na fronteira econômica indica também diferentes níveis de desenvolvimento econômico que, associados a níveis e modalidades de desenvolvimento do modo de vida, sugerem datas históricas distintas e desencontradas no desenvolvimento da sociedade, ainda que contemporâneas. E não me refiro apenas à inserção em diferentes etapas coexistentes do desenvolvimento econômico. Refiro-me sobretudo às mentalidades, aos vários arcaísmos de pensamento e conduta que igualmente coexistem com o que é atual ${ }^{14}$. E não estou falando de atraso social e econômico. Estou falando da contemporaneidade da diversidade. Estou falando das diferenças que definem seja a individualidade das pessoas, seja a identidade dos grupos.

Essa distinção não é conceitual nem é classificatória, ao contrário do que entendem diferentes pesquisadores que trataram da fronteira a partir do surto expansionista de 1964. Nesse equívoco repousa a controvérsia sobre o tempo histórico da frente de expansão e o tempo histórico da frente pioneira, pois não se reconhece que o tempo histórico de um camponês dedicado a uma 
agricultura de excedentes é um, enquanto o tempo histórico do pequeno agricultor próspero, cuja produção é mediada pelo capital, é outro. E é ainda outro o tempo histórico do grande empresário rural. Como é outro o tempo histórico do índio integrado, mas não assimilado, que vive e se concebe no limite entre o mundo do mito e o mundo da História. Como ainda é inteiramente outro o tempo histórico do pistoleiro que mata índios e camponeses a mandado do patrão e grande proprietário de terra: seu tempo é o do poder pessoal da ordem política patrimonial e não o de uma sociedade moderna, igualitária e democrática que atribui à instituição neutra da justiça a decisão sobre os litígios entre seus membros. A bala de seu tiro não só atravessa o espaço entre ele e a vítima. Atravessa a distância histórica entre seus mundos, que é o que os separa. Estão juntos na complexidade de um tempo histórico composto pela mediação do capital, que junta sem destruir inteiramente essa diversidade de situações.

A distinção entre frente pioneira e frente de expansão é, na melhor das hipóteses, um instrumento auxiliar na descrição e compreensão dos fatos e acontecimentos da fronteira ${ }^{15}$. É um instrumento útil quando as duas concepções são trabalhadas na sua unidade, quando destaca a temporalidade própria da situação de cada grupo social da fronteira e permite estudar a sua diversidade histórica não só como diversidade estrutural de categorias sociais, mas também como diversidade social relativa aos diferentes modos e tempos de sua participação na História. No entanto, diferentes pesquisadores a interpretaram como uma tipologia da fronteira e a ela se referiram e a reduziram ao esquematismo classificatório da controvérsia latino-americana dos anos sessenta e setenta sobre o desenvolvimento do capitalismo no campo, sobre a natureza histórica das mudanças (e das lutas sociais) que estavam ocorrendo no campo: eram transformações no capitalismo ou era transição de précapitalismo (e, para alguns, até feudalismo) para o capitalismo?

Tal esquematismo procurou legitimidade no marxismo estruturalista de inspiração althusseriana que se difundiu na América Latina nesse período, sobretudo através de manuais de vulgarização do pensamento de Althusser. Porém, penso que o marxismo estruturalista não pode reconhecer nos processos sociais a diversidade e contemporaneidade dos tempos históricos, porque os separa em agregados referidos à lógica do espaço. Assim, o modo capitalista de produção, em sua perspectiva, é estritamente constituído por um jogo de categorias que, embora contraditórias, tem uma mesma e única data, a do tempo da burguesia e do proletariado. Quase sempre essa data única está subjacente à idéia do capitalismo como sistema (e como conceito) que, por isso, reduz todas as relações, por mais diversificadas que sejam, a uma única, definida como capitalista. O recurso ao conceito estruturalista de formação econômico-social é um artifício que procura manter uma certa idéia de totalidade, porém constituída de níveis, isto é, camadas de realidades desiguais, dotadas de autonomia relativa umas em relação às outras e, portanto, esvaziadas de historicidade. A partir daí não se distingue entre sistema mercantil e 
capitalismo, entre dinheiro e capital, entre propriedade privada e propriedade capitalista (isto é, propriedade de meios de produção destinados à exploração característicamente capitalista da força de trabalho), entre modo de produção capitalista e modo de produção especificamente capitalista, entre processo de trabalho e modo capitalista de produção, etc.

As relações sociais de data diversa, isto é, que encerram outra temporalidade, nessa orientação são reconhecidas unicamente na definição de um outro modo de produção (no fundo, uma espécie de tipo ideal). Ao invés da coexistência de tempos históricos na contradição dos processos sociais, essa orientação reconhece os desencontros dos tempos históricos apenas em termos de articulação de modos de produção ${ }^{16}$ (e não de contradição contemporânea no interior das próprias relações sociais). Além disso, a lógica espacial dessa orientação impõe a distinção de níveis da realidade, ainda que combinados, como se fossem instâncias dotadas de autonomia, como a da economia, da política, da ideologia. São, na verdade, artifícios que permitem classificar a realidade ajustando-se as partes, as peças, numa arquitetura em que o pesquisador apenas intui, mas não demonstra, o lugar de cada uma. Portanto, nessa perspectiva é impossível reconhecer o desencontro dos tempos históricos contidos nas relações sociais reais, como expressão da diversidade na unidade, própria da sociedade capitalista e moderna. E, principalmente, torna-se impossível reconhecer, a não ser por um artifício mecanicista, a possibilidade de transformação do presente e nele a possibilidade da História, a virtualidade da História, a História não só como passado, mas como promessa contida na luta pela vida, pelas concepções da vida como vir a ser, no destino de todos. Sobretudo ela reduz as contradições (e as alternativas que anunciam) ao anúncio de um único destino histórico para todos indistintamente, todas as classes, todos os grupos, todas as histórias singulares (como a dos índios, dos camponeses, dos operários, dos jovens, das mulheres, etc.). No fundo, uma concepção totalitária. Reduz o destino de todos ao destino da burguesia na sua contrafação histórica: a classe média. E não toma como referência, obviamente, o destino do gênero humano na sua diversidade.

\section{Os confins do humano e a fronteira da História}

A categoria mais rica e apropriada para a reflexão sociológica é a de frente de expansão porque ela se refere a lugar e tempo de conflito e de alteridade. Já em Turner (cf. 1956, p. 2), a concepção de fronteira era a do limite entre civilização e barbárie. Em perspectiva oposta, é para Ribeiro limite da civilização. No Brasil, para os próprios membros do que se poderia chamar provisoriamente de sociedade da fronteira ${ }^{17}$, a fronteira aparece freqüentemente como o limite do humano. A fronteira é a fronteira da humanidade. Além dela está o não-humano, o natural, o animal. Se entendermos que a fronteira tem dois lados e não um lado só, o suposto lado da civilização; se entendermos que ela tem o lado de cá e o lado de lá, fica mais fácil e mais abrangente 
estudar a fronteira como concepção de fronteira do humano. Nesse sentido, diversamente do que ocorre com a frente pioneira, sua dimensão econômica é secundária.

O Brasil é um país particularmente apropriado para estudar a fronteira nessa perspectiva. As últimas décadas tem sido uma época em que grupos humanos de diferentes tribos indígenas foram contactados pela primeira vez pelos civilizados. Ao mesmo tempo, civilizados muito diversificados entre si, com mentalidades muito desencontradas a respeito de seu lugar nesse dramático confronto da condição humana e de concepções de humanidade: 0 camponês, o peão, o garimpeiro, o grande fazendeiro, o empresário, o religioso (de diferentes confissões religiosas), o funcionário público, o antropólogo.

$\mathrm{O}$ que poderia ter sido um momento fascinante de descoberta do homem, foi um momento trágico de destruição e morte. Mas, isso não tira a dimensão épica e poética dos fugidios instantes do encontro de diferentes humanidades como tem ocorrido na região amazônica ${ }^{18}$. Para mim, o mais expressivo documento desse ato de achar o outro é a fotografia de um jovem índio da tribo Kreenakarore, o rosto pintado de urucu, espreitando, na floresta, os brancos que os procuravam e os viam pela primeira vez também: os olhos arregalados descobriam e deixavam descobrir uma outra humanidade ${ }^{19}$. Foi em outubro de 1972. A existência dessa tribo havia sido descoberta no dia 6 de fevereiro por um sertanista que sobrevoava a selva, para saber se havia populações indígenas no trajeto por onde passaria a rodovia Cuiabá-Santarém, atraí-las e contactá-las. Nesse dia foi avistada uma de suas aldeias. No dia 14, uma expedição encontrou os primeiros vestígios de sua existência: picadas na mata, restos de fogueiras e ossos de animais. No dia 25 de maio, às $11 \mathrm{~h}$ da manhã, os Kreenakarore atacaram os brancos pela primeira vez e feriram um trabalhador. No dia seguinte, o comando militar encarregado da abertura da estrada suspendeu os trabalhos a apenas $20 \mathrm{~km}$ do acampamento da expedição. No dia 27, um helicóptero retirou o trabalhador que fora flechado pelos índios. Na noite seguinte, os sertanistas ouviram várias vezes o pisar das folhas secas do chão de seu acampamento por visitantes que se tornavam invisíveis quando o foco da lanterna era dirigido para o local de onde vinha o ruído. Isso foi interpretado como sinal de que os índios queriam entrar em contato com os brancos. Na tarde do dia seguinte, os membros da expedição colocaram presentes no local em que o trabalhador fora flechado: facões, machados, facas, colares, peças de alumínio. Assustados pelo tiro que um trabalhador dera num macaco que estava numa copa de árvore sob a qual se encontrava um grupo de índios, e sentindo a aproximação da expedição, os Kreenakarore queimaram sua aldeia e se refugiaram na mata. Mas, deixaram para os brancos vários presentes: bordunas, flechas, arcos. De fato, também eles estavam tentando contactar os brancos. No dia 4 de outubro, os índios recolheram os presentes deixados pelos brancos na margem do rio Peixoto de Azevedo. No dia 15 apareceu nas proximidades um grupo numeroso de índios que falavam alto e gesticulavam muito. No dia 19 , reapareceram na margem esquerda do rio, 
acenando para a expedição. Um dos sertanistas chegou a dez metros de distância de um casal, que o ameaçou retezando o arco e, em seguida, internando-se na mata. No dia 31 de dezembro, os índios começaram a reconstruir a aldeia que haviam queimado. No dia 13 de fevereiro de 1973, eram finalmente atraídos para viver no acampamento dos brancos e contados: eram 350 pessoas. Dois anos depois desses episódios e do contato com os brancos, em janeiro de 1975, só restavam vivos 79 deles (40 homens e 39 mulheres), todos com sinais visíveis de tuberculose. Um ano depois, um sertanista denunciava que brancos podiam ter submetido os índios a severas humilhações, que eles não faziam mais roça e havia entre eles vários casos de doenças venéreas transmitidas pelos brancos, sem contar 35 índios com gripe, inclusive o cacique. Os índios estavam abandonando a aldeia e construindo suas malocas na beira da rodovia, expostos ao contato indiscriminado com os trabalhadores da estrada. Se queremos insistir no nosso conceito de civilização e civilizado, a civilização da frente pioneira havia triunfado sobre a barbárie da selva.

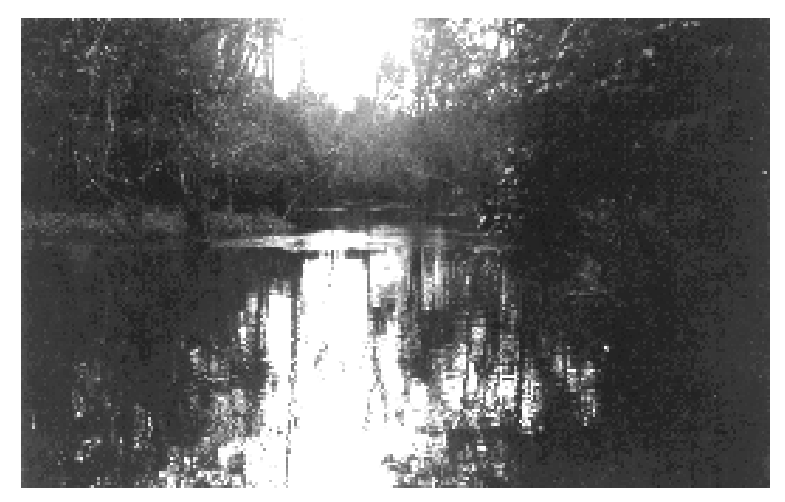

Igarapé no norte do Mato Grosso (1979).

Essa não é uma história única. Pelo menos 34 tribos indígenas foram atraídas e contactadas na Amazônia, a partir de 1965, entre tribos até então desconhecidas e facções arredias de grupos já conhecidos ${ }^{20}$. Sem contar tribos fragmentadas em grupos dispersos, em relação a cada qual o contato foi específico. Vinte e seis delas o foram entre 1970 e 1975 . Na quase totalidade desses grupos a história do contato não varia muito em relação ao caso dos Kreenakarore.

Os brancos utilizam usualmente as palavras atração, pacificação e contato para se referir à ação de neutralização das populações indígenas que geralmente reagem quando percebem que seus territórios estão sendo invadidos. Essas são palavras técnicas do jargão oficial, usadas pelos funcionários da Fundação Nacional do Índio para caracterizar seu trabalho. O homem comum, porém, sintetiza essas diferentes ações no verbo amansar os índios. É uma palavra que dá bem a medida do lugar que o índio ocupa no imaginário do civilizado da fronteira: ele é geralmente classificado como animal (Ribeiro, 1977, p. 362-363).

Várias localidades da Amazônia receberam o nome de São Félix, inclusive no período recente. É que São Félix, na crença católica popular, é o 
santo que protege o homem contra os animais peçonhentos e os índios. $\mathrm{Na}$ região, os não-índios, brancos ou não, chamam a si mesmos de cristãos. E classificam os índios como caboclos, isto é, pagãos, por oposição aos cristãos ${ }^{21}$. Certa vez, em São Félix do Araguaia (no Mato Grosso), caminhando pela rua à beira do rio, ouvi quando algumas crianças começaram a ofender um índio karajá que passava. Perguntei-lhes porque faziam aquilo, pois o índio era gente como elas e elas certamente não gostariam que alguém lhes fizesse o mesmo. Um dos meninos disse-me com espanto: "Ele não é gente como eu. Ele é caboclo e eu sou cristão!" Lembro-me, ainda, do cacique xavante Aniceto, numa reunião em Goiânia, opondo-se aos bispos católicos que, por uma questão de respeito aos índios, não se julgavam no direito de batizá-los. Para Aniceto, o batismo constituía o reconhecimento da humanidade do índio e uma proteção em relação aos brancos que, pela falta do batismo, os consideravam animais. A distinção entre cristão e caboclo é, nesses casos, usada para distinguir os humanos dos bichos-do-mato ${ }^{22}$.

Nesse período recente, não foram raros os casos de expedições de caça ao índio organizadas pelos brancos da frente de expansão, para removêlos de "suas" terras e prevenir ataques. Como em 1963, quando os responsáveis por um seringal no Mato Grosso ordenaram a destruição e o massacre de toda uma aldeia de índios Cinta Larga: de avião, em vôos rasantes, foram jogadas dinamites sobre a aldeia, ao mesmo tempo que uma metralhadora era disparada sobre os índios que corriam em pânico. Os atacantes voltaram por terra e metralharam outro grupo de índios acampados à beira de um rio. Ouvindo um choro abafado de criança, voltaram e encontraram, sob dois corpos crivados de bala, a mãe viva e uma garotinha. Enquanto violentavam a mulher, que matariam depois, com um tiro estouraram os miolos da menina que tentara socorrer a mãe (cf. Ribeiro, 1977, p. 189-190). Isso depois do principal responsável pela firma ter dito diante de testemunhas: "Estes parasitas destes índios sem vergonha... Já é tempo de acabar com eles, de liqüidar com eles... (...) Vamos liqüidar com estes vagabundos." Os Kayapó, no final dos anos 50, eram considerados bichos pelos seringueiros e pelos donos dos seringais e

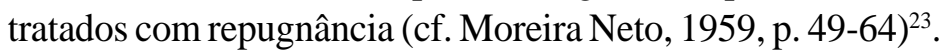

O que se conhece de como os próprios índios de diferentes tribos viram e interpretaram a chegada dos brancos e a invasão de seus territórios por eles é igualmente sugestivo. Quando os Suruí de Rondônia se viram pela primeira vez frente a frente com um grupo de brancos, o assustado cacique a estes se dirigiu dizendo: "Branco, eu te amanso"24. Várias tribos se designam a si mesmas como gente, para diferençar-se dos outros humanos. É o caso dos mesmos Suruí, que, em sua língua, se chamam a si mesmos de paiter, isto é $a$ gente (nós mesmos) "em detrimento de outros, que não seriam humanos" (cf. Mindlin, 1985, p. 99). Nas concepções dos Bororo, do Mato Grosso, os civilizados estão na mesma categoria dos seres maléficos e mortais, isto é, são semelhantes, mas não idênticos, às cobras venenosas, aos inimigos e aos espíritos maléficos, designados por Bope (isto é, coisa ruim). Em suas 
concepções, o gado bovino é reconhecido como companheiro dos civilizados porque destrói plantações e, desse modo, rouba alimento dos índios. Aliás, a vaca não possui um lugar no cosmo Bororo (cf. Viertler, 1990, p. 19-32).

Juruna, um índio Xavante, entende mesmo que, no rio das Mortes, foram os índios que atraíram e amansaram os brancos: "Deu muito trabalho atrair branco. Branco sempre com medo. Foi uma luta amansar branco. Branco matou muito índio, até Xavante poder amansar branco"(cf. Martins, E., 1978, p. 208) ${ }^{25}$. Mesmo amansado, o branco permanece excluído do mundo xavante. Em seu excelente estudo sobre esses índios, Aracy Lopes da Silva sublinha que o dualismo de seu pensamento e de sua organização social se expressa na classificação de "nós" e "eles". As cisões internas "dão lugar ao surgimento de uma consciência que se expressa na concepção de um 'nós' sempre ampliado" que, em certas circunstâncias, "extravasa os limites do mundo Xavante e passa a incluir os outros índios". Trata-se de uma cultura em que há "a necessidade lógica dos muitos 'outros' com que, nas sociedades Jê, se constrói a noção de pessoa e de identidade individual...". E conclui que "à falta do branco, ou melhor, à falta de meios para enfrentar o branco (...) ele seja substituído pela onça: igualmente outro, elemento da natureza, assim como o branco excluído do universo cultural xavante" (cf. Silva, 1986, p. 55 e p. 257-258).

Para o índio o avanço da frente de expansão não repercute apenas por colocá-lo diante de uma humanidade diferente, a dos civilizados. Repercute nos rearranjos espaciais de seus territórios e nas suas relações com outras tribos, sobretudo as inimigas. Essas mudanças resultam em muitas perdas, não só do território, mas também de vidas e de elementos culturais. Os Asurini do Xingu não só estavam sendo acossados pelos civilizados desde o século passado, como também por tribos vizinhas e inimigas que os atacaram várias vezes e os forçaram a deslocar-se em diferentes ocasiões. Foram expulsos do Ipixuna pelos Araweté, que por sua vez estavam sendo atacados pelos KayapóXikrin e pelos Parakanan. No Ipixuna cultivavam 76 variedades de plantas, "mas, devido à retirada precipitada que efetuaram quando foram atacados pelos Araweté, só conduziram 46, e destas estão cultivando apenas 11" (cf. Arnaud, 1989, p. 353) ${ }^{26}$.

Muito antes da linha fronteiriça definir o limite da presença do civilizado num território determinado, a frente de expansão já se expande indiretamente empurrando os grupos indígenas mais próximos para territórios de seus vizinhos mais distantes. No geral, tem decorrido daí guerras intertribais e até o extermínio de algumas populações indígenas por parte de outros grupos indígenas. A escassez de estudos que combinem a etnohistória com a história dificulta uma visão ampla desse imenso e múltiplo conflito que se dá além da fronteira, que se mostra, assim, além do mais, fronteira da História, como resultado da histórica expansão da sociedade civilizada.

Os preciosos estudos de Dominique Gallois sobre o povo Waiãpi, que vive hoje na fronteira com a Guiana francesa, são justamente indicativos 
da importância que tais estudos podem ter para melhor compreensão dos aspectos propriamente dramáticos da expansão da fronteira. Desde o final do século XVII e início do século XVIII, os Waiãpi vem migrando em direção ao norte e à Guiana. Deslocaram-se fugindo, empurrados pelos brancos, desde o rio Xingu. Atravessaram o rio Amazonas e se localizaram na região do rio Jari, avançando, depois, em direção às suas cabeceiras. Nessa lenta migração de cerca de trezentos anos, há muitos episódios de guerra com outras tribos cujos territórios estavam invadindo. Como há episódios de cooptação pelos civilizados para que se empregassem na caça de outros índios para reduzi-los à condição de escravos. Sem contar complicados arranjos e relacionamentos entre tribos indígenas para efetivar um comércio primitivo de ferramentas produzidas pelos civilizados (cf. Gallois, 1986 e 1993) ${ }^{27}$.

Os estudos de Gallois sobre esse povo mostram uma complexa e surpreendente teia de relacionamentos entre diferentes grupos indígenas, incluindo um grupo de ex-escravos negros fugidos das fazendas da Guiana francesa e retribalizados, para fazer circular esses produtos entre eles. Um comércio inteiramente extra-capitalista e, até se poderia dizer, extra-comercial porque inteiramente estranho aos princípios e realidades econômicos em que esses produtos foram gerados. Sobretudo porque nesse mundo indígena e tribal tais mercadorias estão separadas de seu mundo de origem por uma nítida fronteira social e cultural e por uma lógica de circulação de produtos inteiramente diversa, distante de qualquer concepção de equivalência. Isso fica claro na destruição de bens até caros, procedentes dos civilizados, por ocasião dos rituais fúnebres dos respectivos donos, em diferentes tribos ${ }^{28}$. A mercadoria é apenas adicionada à cultura tribal, mas não incorporada segundo sua implícita lógica mercantil e acumulacionista. Provavelmente, porque a mercadoria só pode sê-lo se conservar o valor de uso, que se manifesta nas circunstâncias inclusive culturais em que é usada. Enquanto o branco põe a ênfase de sua relação com a mercadoria no valor de troca, mesmo quando a usa (e já não tem valor de troca), o índio põe a ênfase no valor de uso e numa concepção de uso que anula o "pecado original" da troca.

Diversas tribos indígenas contactadas no período recente foram surpreendidas migrando lentamente, por longas distâncias, para o interior do país em consequiência de pressões anteriores da frente de expansão, diretamente sobre elas ou sobre seus vizinhos: os Tapirapé se fixaram no Mato Grosso após um longo percurso a partir do Maranhão; os Xavante estão agora encurralados no Mato Grosso, entre fazendas de gado e lavouras de camponeses pobres, mas procedem de Goiás e da Bahia ${ }^{29}$. Há mesmo casos de tribos originárias de um ambiente ecológico específico que, em consequiência dessas migrações, deslocaramse para ambientes completamente diferentes, o que as obrigou, em alguns casos com sucesso e em outros sem sucesso, a reelaborarem sua relação com a natureza, sua cultura e suas concepções: os Iranxe, originários da região de mata, onde haviam elaborado "sua experiência histórica de vida", foram deslocados para o cerrado, onde se adaptam mal; já os Kayapó foram empurrados do cerrado para a floresta 


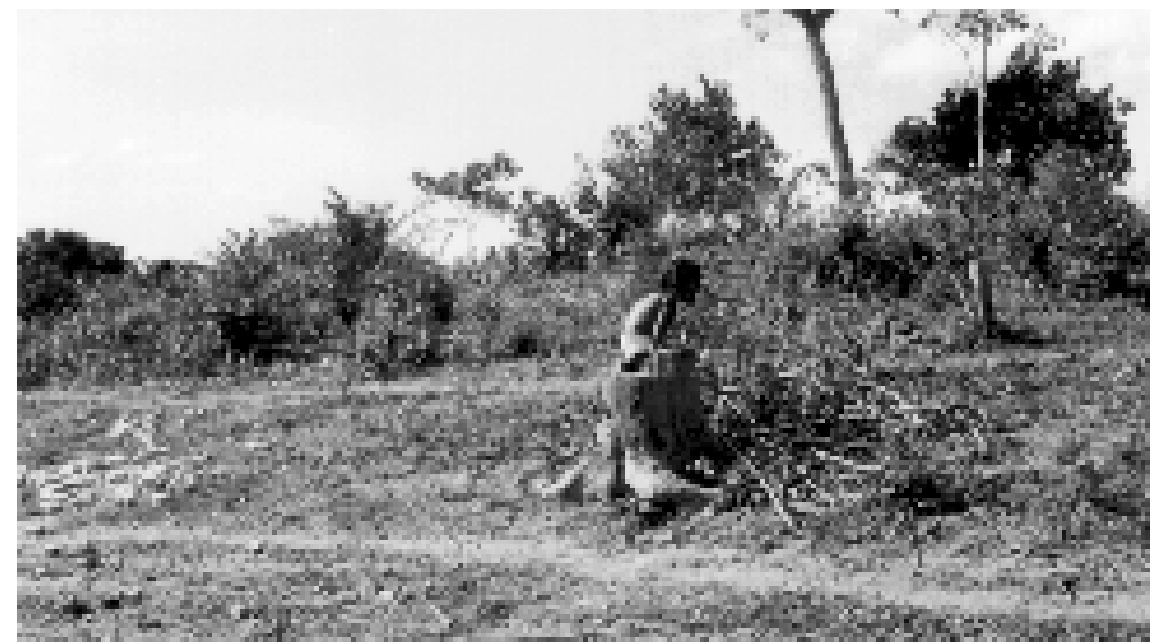

e levaram mais de cem anos para se adaptarem ao novo ambiente e produzirem conhecimentos a ele adequados (cf. Pivetta, 1993, p. 19 e p. 39-47).

Em vários casos, a chegada dos civilizados se deu praticamente no mesmo período de confrontos devastadores entre diferentes tribos. Há pouco menos de meio século, um etnólogo relatava o estado de pânico que se apossara dos índios Tapirapé, do Mato Grosso, em relação aos seus mais perigosos inimigos, os Kayapó. A mais intensa aproximação da frente de expansão de seu território coincidia com o fato de que "os Kayapó não somente avançam em direção ao Araguaia para acabar com os sertanejos e suas casas. Marcham para o sul atacando Tampiitaua", a aldeia tapirapé (cf. Baldus, 1970, p. 49) ${ }^{30}$. O encontro, portanto, para esses grupos, se deu em momentos dramáticos, acrescentando um inimigo de certo modo inesperado aos inimigos conhecidos. Compreende-se que várias dessas tribos tenham aceito e até procurado a sujeição aos brancos. E tenham imediatamente se disposto a colaborar na atração e contato de tribos inimigas. Freqüentes vezes, no fundo, os índios imaginaram que estavam envolvendo os civilizados em seus próprios conflitos. Só recentemente diferentes grupos indígenas se deram conta do que estava de fato acontecendo e passaram a se aliar a seus antigos inimigos para enfrentar os brancos. Esse é certamente um dos aspectos novos da expansão da fronteira no Brasil. E outro aspecto novo e fundamental é que populações indígenas tem pressionado os brancos, com êxito, no sentido da expansão das fronteiras de seus territórios de confinamento, como tem se dado com os Kayapó; ou reocupando fazendas abertas em seus antigos territórios, inclusive instalações, como ocorre com os Xavante.

Esse cenário de conflito não se desenha necessariamente sobre o imaginário de um território aberto e ilimitado. Lux Vidal, no seu minucioso estudo sobre os Kayapó-Xikrin, relata que eles "reconhecem dois pontos cardeais: leste e oeste". E que, em oposição ao leste, que é bem definido, por ser o lugar de sua origem e de origem de seus mitos, "o oeste é simplesmente um ponto de referência convencional de delimitação do espaço (...), mas, não
Jovem índio tapirapé observa o rio no embarcadouro de sua aldeia assediada pelas fazendas de gado das grandes empresas do Sudeste (1979). 
Família de peões escravisados por dívida trabalhando na derrubada da mata, na frente pioneira de Jaru, Rondônia (1977). definido, ninguém poderia situá-lo. Segundo os índios “é o fim do mundo"'.É também o lugar da noite perpétua (cf. Vidal, 1977, p. 18 e 21). Segundo Gallois, também os Waiãpi, no mito em que se referem ao lugar Mairi, mencionam que ali está o buraco do final da terra. Na sua reconstituição da relação entre mito e História, Gallois descobriu que Mairi é a cidade de Almeirim, antiga localidade de referência, embora distante, da fortaleza de Macapá, construída pelos portugueses no período colonial. Há nessa fortaleza o que parece ser um calabouço em forma de poço. Um índio conhecedor do mito, ao visitar a fortaleza pela primeira vez, disse: "Quando conheci a fortaleza, reconheci o lugar". O "buraco do final da terra" era o lugar onde "jogavam as pessoas". De qualquer modo, ali efetivamente termina a terra, como terminava a vida; depois dali é o oceano (cf. Gallois, 1993, p. 17).

\section{A disputa pela concepção de destino na situação de fronteira}

Quem conhece a fronteira sabe perfeitamente que nela, de fato, essas "faixas" se mesclam, se interpenetram, pondo em contato conflitivo populações cujos antagonismos incluem o desencontro dos tempos históricos em que vivem. A recente expansão da fronteira mostrou isso de maneira muito clara. Práticas de violência nas relações de trabalho, como a escravidão por dívida, próprias da história da frente de expansão, são adotadas sem dificuldade por modernas empresas da frente pioneira. Pobres povoados camponeses da frente de expansão, permanecem ao lado de fazendas de grandes grupos econômicos, equipadas com o que de mais moderno existe em termos de tecnologia. Missionários católicos e protestantes, identificados com as orientações

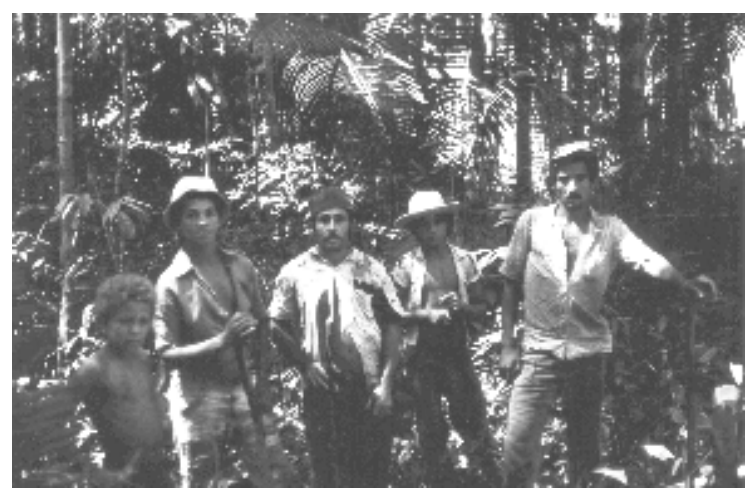

teológicas modernas da Teologia da Libertação encontram lugar em suas celebrações para as concepções religiosas tradicionalistas do catolicismo rústico, próprio da frente de expansão ${ }^{31}$.

A dinâmica da frente de expansão não se situa num único mecanismo de deslocamento demográfico. Tradicionalmente, a frente de expansão se movia e excepcionalmente ainda se move, em raros lugares, em conseqüência de características próprias da agricultura de roça. Trata-se de um deslocamento lento regulado pela prática da combinação de períodos de cultivo e períodos 
de pousio da terra. Depois de um número variável de anos de cultivo do terreno, os agricultores se deslocam para um novo terreno. Onde essa prática é mais típica, como o Maranhão, o deslocamento se dá no interior de um território de referência ao redor de um centro, de um povoado. Quando a roça fica distante do centro, a tendência é a criação de um novo centro, ao redor do qual os lavradores abrem suas roças segundo critérios de precedência e antigüidade dos moradores e segundo concepções de direito muito elaboradas, isto é, quem tem direito de abrir roça onde, por exemplo. Desse modo, a fronteira se expande em direção à mata, incorporando-a à pequena agricultura familiar.

A tendência observada até agora é a da aceleração do deslocamento da frente de expansão, ou mesmo seu fechamento, em decorrência da invasão das terras camponesas por grileiros, especuladores, grandes proprietários e empresas $^{32}$. Quando não integrados no mercado de trabalho, os camponeses eram e são expulsos de suas terras e empurrados para "fora" da fronteira econômica ou para "dentro" como assalariados sazonais. Se encontram terras livres mais adiante, continuam a tendência migratória, mesmo que para pontos mais distantes. É notável a circulação de informações sobre terras livres ou presumivelmente livres, entre camponeses, centenas de quilômetros adiante. A teia de relações de parentesco e de compadrio se encarrega de difundir as informações sobre a localização de novas terras que ainda podem ser ocupadas. O que é facilitado pelo lento deslocar de fragmentos de grupos famíliares desses camponeses. Embora tendencialmente migrem em família e até em grupo $^{33}$, há uma rede familiar mais extensa e viva que constitui a referência nesse movimento. Em cada etapa do deslocamento, os membros da família, os compadres, os antigos vizinhos já chegados acolhem os que vêm depois e serão acolhidos mais adiante pelos que se foram antes (cf. Keller, 1975, p. 674). A verdadeira estrutura social de referência das populações camponesas da fronteira não é a local e visível. Ela se espalha por um amplo território, num raio de centenas de quilômetros, e é uma espécie de estrutura migrante, uma estrutura social intensamente mediada pela migração e pela ocupação temporária, ainda que duradoura, de pontos do espaço percorrido. Os estudos sociológicos que tomam como referência uma localidade específica não apanham a realidade social mais profunda que dá sentido à existência dessa espécie de sociedade transumante.

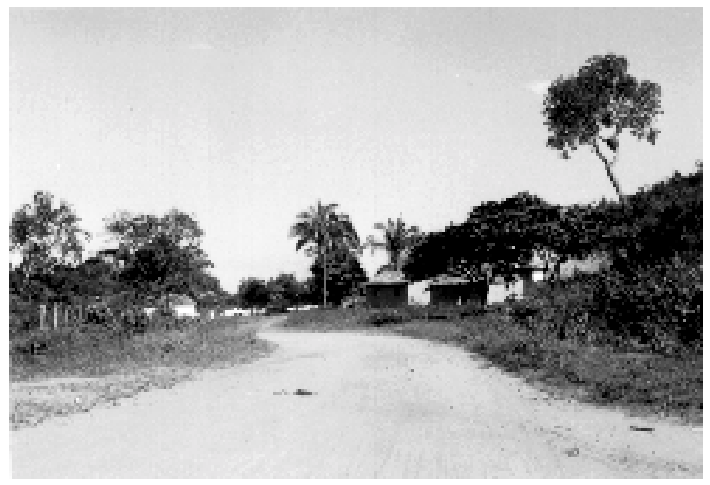

Sta. Terezinha, antigo povoado de posseiros no norte do Mato Grosso, local de conflito armado com jagunços de um banco paulista, em 1973 (1979). 
Quando não há perspectiva de encontrar novas terras nem há perspectiva ou disposição de entrar na economia da miséria no interior da fronteira econômica, geralmente começa a luta pela terra, o enfrentamento do grande proprietário e seus jagunços. Em algumas regiões tem sido possível, nos últimos vinte anos, observar a passagem das migrações espontâneas, decorrentes da saturação da terra, para as migrações forçadas pelas expulsões violentas da terra. Eobservar, neste último caso, que mesmo aí os camponeses migram para não muito longe, como que circulando ao redor de um ponto ou ao longo de uma rota de referência. Quando a pressão se combina com a falta de alternativa, surge o conflito, como ocorreu em vários pontos do sul do Pará (Hébette, s/d., p. 1-3). A história recente das lutas camponesas no Brasil tem, aliás, mostrado abundantemente que mesmo quando não se configura a falta de alternativas, os camponeses ameaçados optam pela luta pela terra, pelo questionamento seja dos supostos direitos dos alegados proprietários seja da própria legitimidade desses direitos. As diferentes modalidades de acomodação desses conflitos por parte do Estado, com as desapropriações de terras para reforma agrária, até preventivamente nos casos de probabilidade de tensão social, mostram que os trabalhadores rurais, ainda que por via indireta, conseguiram abrir uma alternativa poderosa e em grande parte sua numa situação de aparente falta de alternativas ${ }^{34}$.

São eles, por isso, agentes característicos da frente de expansão, embora não sejam os únicos nem necessariamente os decisivos. Por isso, violam a linha da fronteira demográfica e avançam sobre territórios que são sempre territórios tribais, isto é, territórios de algum modo incluídos no circuito de perambulação de algum grupo tribal. Além das situações de conflito com as populações indígenas que procuram resistir a esse avanço, há também as situações de fuga dos mesmos indígenas, que se deslocam mais para o interior à procura de novos espaços, geralmente às custas de graves conflitos entre as próprias populações indígenas, de tribos diferentes ou até do mesmo grupo

Pedro Afonso, Goiás, povoado e município decadente da antiga frente de expansão do Tocantins, onde os tempos se combinam: as casas de adobe e palha e as casas de alvenaria (1984).

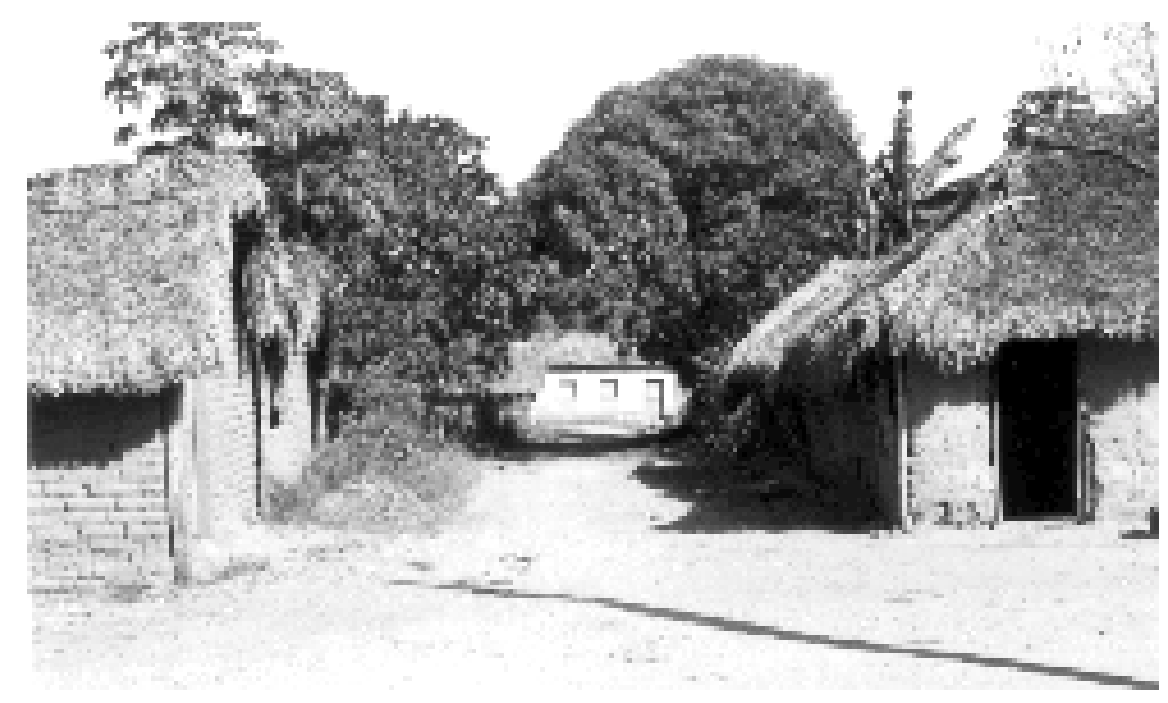


indígena (como tem ocorrido entre facções da grande nação Kayapó).

O conjunto da informação histórica que hoje se tem sobre a frente de expansão e a frente pioneira sugere que a primeira foi a forma característica de ocupação do território durante longo período. Começou a declinar com a chamada Marcha para Oeste, em 1943, e a intervenção direta do Estado para acelerar o deslocamento dos típicos agentes da frente pioneira sobre territórios novos, em geral já ocupados por aqueles que haviam se deslocado com a frente de expansão. Tipicamente, a frente de expansão foi constituída de populações ricas e pobres que se deslocavam em busca de terras novas para desenvolver suas atividades econômicas: fazendeiros de gado, como ocorreu na ocupação das pastagens do Maranhão por criadores originários do Piauí; seringueiros e castanheiros que se deslocaram para vários pontos da Amazônia. E mesmo agricultores. Levaram consigo seus trabalhadores, agregados sujeitos a formas de dominação pessoal e de exploração apoiadas no endividamento e na coação.

Quando a economia da borracha entrou em crise e decadência aí por 1910, muitos desses empreendimentos extrativos, que eram essencialmente comerciais e não agrícolas, simplesmente encerraram suas atividades. Ficaram para trás os trabalhadores, dedicados à própria subsistência e comercialização de excedentes em pequena escala. Essencialmente, houve um refluxo da economia, expresso diretamente no retorno a uma economia baseada na produção direta dos meios de vida por parte dos trabalhadores (cf. Ianni, 1978, esp. p. 64). Isso tinha sentido, porque os donos de seringais e castanhais eram meros posseiros ou foreiros que haviam arrendado suas terras do Estado. Portanto, a partir desse momento, a frente de expansão ficou caracterizada como uma frente demográfica de populações camponesas e pobres residualmente vinculadas ao mercado. Ao invés de estagnar, continuou crescendo e se expandindo pela chegada contínua de novos camponeses sem terra originários sobretudo do nordeste, no caso da Amazônia, que foram ocupando as terras real ou supostamente livres da região.

Uma característica importante da frente de expansão em todo o país, para datá-la historicamente, é que quando se deslocavam juntos ricos e pobres, deslocavam-se com base nos direitos assegurados pelo regime sesmarial. Embora o regime de sesmarias tenha cessado às vésperas da Independência e só tenha sido substituído por um novo regime fundiário com a Lei de Terras de 1850 , ele continuou norteando as concepções de direito à terra de ricos e pobres e, em muitos casos, norteia até agora.

Ainda hoje, quando um posseiro da Amazônia justifica seu direito à terra, ele o faz invocando o direito que teria sido gerado pelo trabalho na terra. Ao mesmo tempo, reclama e proclama que seu direito está referido aos frutos de seu trabalho, que por serem seus está no direito de cedê-los ou vendêlos. A concepção de que é preciso ocupar a terra com trabalho (na derrubada da mata e no seu cultivo) antes de obter reconhecimento de direito, era próprio do regime sesmarial. Do mesmo modo, a concepção de que o trabalho gera direito de propriedade sobre os frutos do trabalho também era própria desse 
regime fundiário. Nele, o domínio estava separado da posse. O domínio era da Coroa. Quando, por acaso, o sesmeiro deixasse de cultivar a terra ou de obter dela frutos para pagar tributos, a terra se tornava devoluta (ou realenga, como então se dizia, isto é pertencente ao rei). Podia por isso ser novamente distribuída pelo representante da Coroa, bastando que alguém a ocupasse e, depois, a requeresse, como ocorreu freqüentemente. Do mesmo modo, a casa de um agregado construída em terras de sesmaria ou data de outrem, bem como suas roças e cultivos, não sendo ele escravo, lhe pertenciam legalmente, sendo a relação com o sesmeiro apenas relação de enfiteuse. Portanto, o trabalho de fato gerava direito sobre bens produzidos e sobre a terra beneficiada ou, melhor, sobre o benefício incorporado à terra, como era o caso do desmatamento.

É comum encontrar-se nos arquivos documentos de transferência da propriedade de uma casa a um terceiro, construída em terras de um segundo, que apenas recebia o laudêmio, um tributo quase simbólico de reconhecimento do seu senhorio e não de sua propriedade (já que o proprietário eminente era o rei). A Lei de Terras de 1850 é que juntaria num único direito, o de propriedade (mantendo, porém, separados os conceitos), a posse e o domínio. O vocabulário e o imaginário monárquicos, ainda tão fortes nas frentes de expansão, não são devidos unicamente a arcaísmos religiosos, mas também a uma concepção de direito muito próxima dos pobres: a dos direitos (de uso) gerados pelo trabalho em oposição aos direitos (de propriedade) gerados pelo dinheiro ${ }^{35}$.

A partir de 1943, a frente pioneira que, em outras regiões se movia impulsionada pelos interesses imobiliários do grande capital, das empresas ferroviárias e da grande agricultura de exportação, como o café, no Sudeste, na Amazônia passa a depender da iniciativa do governo federal. Ela se torna a forma característica de ocupação das novas terras. Os grandes episódios desse impulso foram a Expedição Roncador-Xingu e a Fundação Brasil Central, ambas oficiais, nos anos 40; a construção da rodovia Belém-Brasília, nos anos 50; e, finalmente, a política de incentivos fiscais da ditadura militar a partir dos anos $60^{36}$. A política de incentivos, ao subsidiar a formação do capital das empresas amazônicas, dando-

Rodovia Transamazônica na entrada de Altamira (Pará). Ao fundo, o rio Xingu (1985).

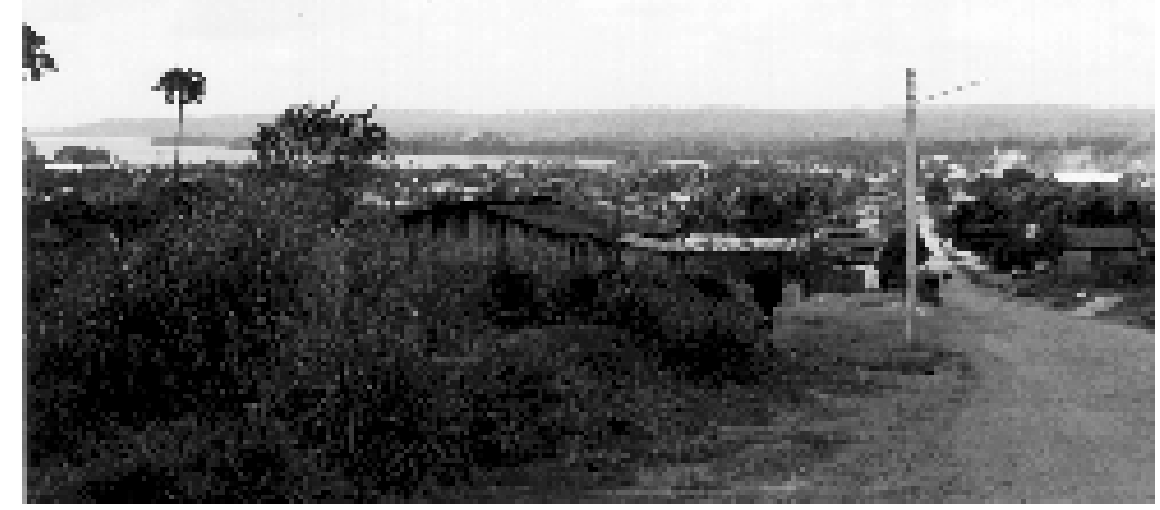


lhes assimuma compensação pela imobilização improdutiva de capital na aquisição de terras para abertura das fazendas (onde era esse o caso), promoveu a aliança entre os grandes proprietários de terra e o grande capital.

Nesse quadro, o deslocamento da frente pioneira sobre as terras já ocupadas pela frente de expansão foi acelerado ${ }^{37}$ e deu à superposição dessas distintas frentes de ocupação territorial uma violenta dimensão conflitiva. Tornaram-se freqüentes e numerosos os despejos violentos e dramáticos de posseiros das terras que ocupavam. Com ou sem base em decisão judicial, os supostos donos, muitas vezes apoiados em documentos falsos, têm conseguido com facilidade o reconhecimento de direitos indevidos. A aceleração do avanço da frente pioneira em diversas regiões adiantou-se à própria frente de expansão e entrou diretamente em contato com as populações indígenas. Se nos anos 70, no Mato Grosso, a distinção entre as duas modalidades de ocupação territorial ainda podia ser facilmente feita, o mesmo não se deu nos anos 80, no Pará. Aqui os índios ainda em fase incipente de integração na sociedade nacional combateram diretamente as grandes empresas modernas que se instalavam em sua região com grandes fazendas, interditando-lhes o acesso às terras que pretendiam ocupar. Foi o que ocorreu especialmente com os Kayapó. No Mato Grosso, os Xavante e os Bororo só reagiram contra os fazendeiros após passar um certo tempo de sua pacificação. Especialmente os primeiros, atacando fazendas já instaladas em seus antigos territórios e retomando-as.

Porém, o avanço da frente pioneira sobre a frente de expansão e a conflitiva coexistência de ambas é mais do que contraposição de distintas modalidades de ocupação do território. Ao coexistirem ambas na situação de fronteira, dão aos conflitos que ali se travam, entre grandes proprietários de terra e camponeses e entre civilizados, sobretudo grandes proprietários, e índios, a dimensão de conflitos por distintas concepções de destino. E, portanto, dimensão de conflitos por distintos projetos históricos ou, ao menos, por distintas versões e possibilidades do projeto histórico que possa existir na mediação da referida situação de fronteira. Essa situação de fronteira é um ponto de referência privilegiado para a pesquisa sociológica porque encerra maior riqueza de possibilidades históricas do que outras situações sociais. Em grande parte porque mais do que o confronto entre grupos sociais com interesses conflitivos, agrega a esse conflito também o conflito entre historicidades desencontradas.

No meu modo de ver, o encontro de relações sociais, mentalidades, orientações historicamente descompassadas, até propriamente no limite da História, introduz a mediação das relações mais desenvolvidas e poderosas na definição do sentido das relações mais "atrasadas" e frágeis, ou melhor, das relações diferentes, com outras datas e outros tempos históricos. A sobreposição da frente pioneira e da frente de expansão produz uma situação de contemporaneidade dessas relações de tempos distintos. E nela a mediação das relações mais desenvolvidas faz com que a diferença apareça, na verdade, como atraso. As relações mais avançadas, mais caracteristicamente 
Mandioca pubando na água do igarapé para fabricação de farinha em roça de posseiro, na frente de expansão do norte do Mato Grosso (1979). capitalistas, por exemplo, não corroem nem destroem necessariamente as relações que carregam consigo a legitimidade de outras épocas. Portanto, nesses casos, a diferença não tem sentido como passado, mas como contradição e nela como um dos componentes do possível, o possível histórico de uma

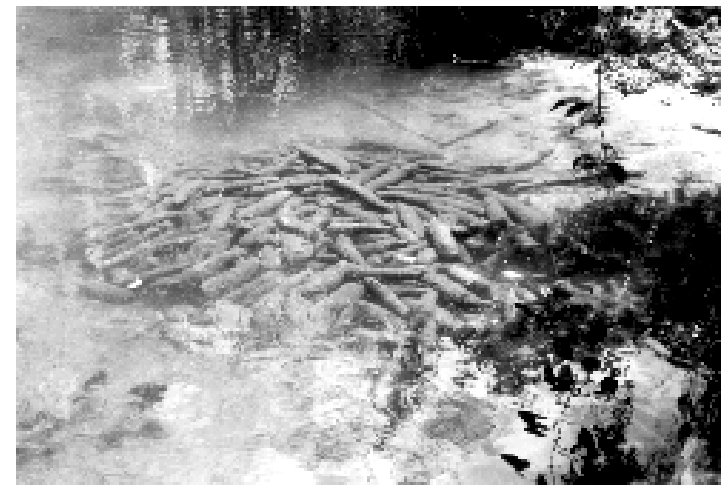

sociedade diversificada, que ganha sua unidade na coexistência das diferenças sociais e étnicas. Seria muito ingênuo imaginar que elas constituem uma receita de tendências históricas.

Isso não quer dizer, muito ao contrário, que o capital não estenda sobre o território da frente de expansão uma rede de relações comerciais para nelas integrar os produtos da indústria extrativa ou mesmo os produtos agrícolas, especialmente os que são típicos da subsistência regional, como a farinha de mandioca, o arroz, etc. Ou, até, estenda seus vínculos diretamente às populações indígenas acuadas, como têm feito as grandes empresas na extração de madeira e minérios nos últimos tempos. E isso não transforma nem os camponeses nem os índios em típicos operários de empresa capitalista. Isso não impede, também, que grandes empresas, dotadas de organização empresarial e técnica moderna e sofisticada, recorram à peonagem, isto é, a escravidão por dívida, sobretudo nas atividades de derrubada da mata e de implantação de suas fazendas, o que é próprio dos seringais e castanhais da frente de expansão. Como não impede, ainda, que bolsões de populações indígenas e camponesas sobrevivam no interior da frente pioneira, ou mesmo em regiões de ocupação antiga, como ocorre no Nordeste e no Sul do país, ainda que num certo sentido enclausuradas em terras de menor interesse econômico ou em territórios demarcados. E que, a partir daí, se integrem marginalmente (ou não) no mercado de produtos agrícolas.

\section{Sobrevivência e milenarismo no mundo residual da expansão capitalista}

Justamente essa primeira constatação da diversidade das temporalidades históricas na fronteira sugere a possibilidade de um equívoco no uso das concepções de frente de expansão e frente pioneira como instrumentos de classificação e definição dessa realidade. Ainda que os geógrafos tenham acentuado a importância da urbanização, das modernas vias 
de comunicação, dos empreendimentos econômicos modernos, da mentalidade moderna, sugeriram com razão a precedência dos fatores econômicos no deslocamento da frente pioneira, o principal dos quais, sem dúvida, a conversão da terra em mercadoria. Entretanto, os que incorporaram a distinção entre frente de expansão e frente pioneira, simplificadamente, como instrumentos de classificação e definição da realidade da fronteira, transferiram, inclusive os críticos, a precedência do econômico para a análise também da frente de expansão ${ }^{38}$. Com isso, o que é próprio e característico dessa última situação de fronteira se desfigura, aparecendo como etapa (e não como expressão de contradição), por exemplo, na expansão do capital na Amazônia.

No meu modo de ver, as relações sociais (e de produção) na frente de expansão são predominantemente relações não-capitalistas de produção mediadoras da reprodução capitalista do capital. Isso não faz delas outro modo de produção. Apenas indica uma insuficiente constituição dos mecanismos de reprodução capitalista na frente de expansão. Insuficiência que decorre de situações em que a distância dos mercados e a precariedade das vias e meios de comunicação comprometem a taxa de lucro de eventuais empreendedores. Portanto, aí tendem a se desenvolver atividades econômicas em que não assumem forma nem realidade própria os diferentes componentes da produção propriamente capitalista, como o salário, o capital e a renda da terra. Os meios de produção ainda não aparecem na realidade da produção como capital nem a força de trabalho chega a se configurar na categoria salário. Portanto, o produtor não tem como organizar sua produção de modo capitalista, segundo a racionalidade do capital. O capital só entra, só se configura, onde sua racionalidade é possível.

Se a frente pioneira se define essencialmente pela presença do capital na produção, o mesmo não ocorre, portanto, na frente de expansão, que não se constitui pela precedência do que nós definimos como econômico na

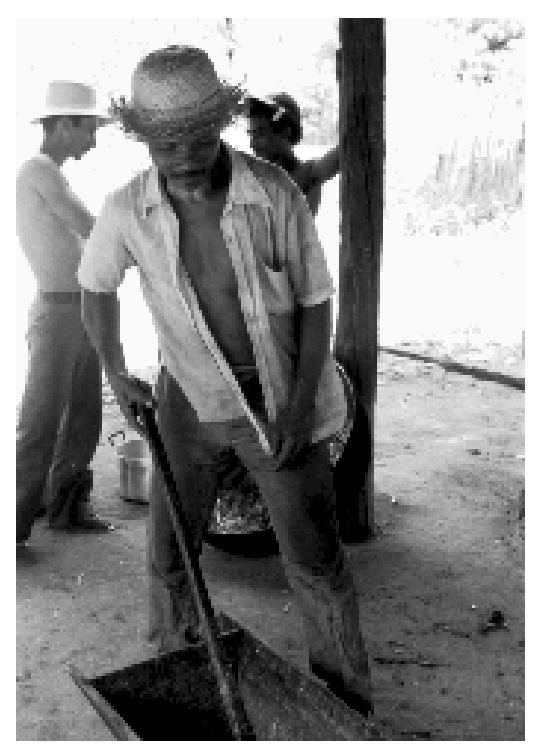

"Seu" Roxo, posseiro de economia excedente, apura o caldo de cana para fazer rapadura, seu açúcar caseiro, em Sta. Terezinha, Mato Grosso (1985). 
constituição de seus modos de vida e da mentalidade de seus agentes. Embora sua dinâmica resulte da ação e dos interesses do capital, combinados com as concepções próprias do camponês e mesmo do índio integrado ${ }^{39}$.

A frente de expansão tornou-se, no fundo, o mundo residual da expansão capitalista, o que está além do território cujas terras podem ser apropriadas lucrativamente pelo capital. Explico-me: tanto Monbeig quanto Waibel mostraram claramente que na frente pioneira o capital se torna proprietário de terra, recria no terreno os mecanismos da sua reprodução ampliada. Expande-se sobre o território, de que se apossa como seu território. Essa expansão territorial traz para a própria fronteira a infraestrutura da reprodução capitalista do capital: o mercado de produtos e de força de trabalho e com ele as instituições que regulam o princípio da contratualidade das relações sociais, que é o que caracteriza a sociedade moderna. O mercado se constitui na mediação essencial que dá sentido ao processo de ocupação do território.

A frente de expansão também é expansão de relações mercantis. Mas, numa concepção inversa à da expansão da produção propriamente capitalista. As relações que na história da fronteira no Brasil tem precedido o avanço da frente pioneira propriamente dita não se caracterizam pela ação do empreendedor que expande a reprodução capitalista do capital no território novo. Antes, sua ação é no sentido de estender as relações mercantis além dos limites do território propriamente incorporado na reprodução capitalista do capital. Há um limite além do qual não é possível extrair renda capitalista da terra. Provavelmente por isso, os territórios sobre os quais se move a frente de expansão são claramente marcados pela ausência da propriedade fundiária moderna, predominando a posse efetiva ou o aforamento. A teoria da fronteira é, no meu modo de ver, basicamente um desdobramento da teoria da expansão territorial do capital. Novos terrenos são ocupados de modo capitalista quando é possível extrair deles a renda capitalista da terra, ao menos a renda absoluta, isto é, quando é possível embutir nos preços dos produtos nela cultivados, além da renda territorial, a taxa média de lucro do capital ${ }^{40}$. Se a distância em relação ao mercado a que o produto se destina implica em transferir ao transporte esse lucro, nenhum capitalista estará interessado em investir em atividades econômicas geograficamente localizadas além de um certo limite ${ }^{41}$. Se o capitalista tiver que deduzir do seu lucro o preço do transporte para fazer o produto chegar ao mercado e aí realizar o seu ganho, ele certamente haverá de considerar a alternativa de outros investimentos para seu capital.

Além desse limite, está a frente de expansão, mas não a frente pioneira. Por isso, a frente de expansão está mais próxima da economia mercantil simples do que da economia capitalista e, ao mesmo tempo, está próxima da mera economia de subsistência. $\mathrm{O}$ camponês produz aí seus próprios meios de vida, além dos excedentes comercializáveis. Ele não pode se inserir plenamente na divisão social do trabalho que rege o conjunto da economia. Porque se o fizer, terá que se especializar, dedicar-se de preferência aos produtos mais rentáveis naquela terra e naquele lugar. Eadquirir no mercado 
seus meios de vida. Ora, os meios de vida que circulam através do mercado são meios de vida cujo preço incorporou a taxa de lucro do capital que os produziu e/ou que os comercializou. Desse modo, eles impõem à reprodução de seus consumidores e da força de trabalho a rentabilidade e a mediação do capital. Para que a força de trabalho se reproduza terá que receber por seu produto o seu valor, isto é, o que foi dispendido em meios de vida por quem trabalha, pois do contrário a força de trabalho não poderá reproduzir-se. Onde a distância do mercado não viabiliza a extração da renda capitalista da terra, o camponês terá que organizar sua economia em outras bases. Ele terá que produzir e assegurar seus próprios meios de vida. Com isso, poderá vender seus produtos como excedentes e não como produtos cujo preço de venda pelo produtor esteja eventualmente baseado numa contabilidade de custos, como ocorre na atividade organizada em bases empresariais. Isso fica mais claro se considerarmos os produtos que tanto são produzidos na frente de expansão quanto na frente pioneira e nas regiões antigas.

No Brasil, de modo geral, um desses produtos é o arroz. Até a uma certa distância do mercado consumidor, o arroz poderá ser produzido de modo empresarial, como ocorre nas grandes regiões arrozeiras do sul, do sudeste e do centro-oeste. A partir desse limite, istoé, além da frente pioneira, não poderá ser produzido de modo empresarial. A partir daí terá que ser produzido sem que o produtor possa assegurar sua sobrevivência apenas com sua comercialização. Em conseqüência, a sobrevivência do agricultor dependerá de que ele possa assegurar essa sobrevivência por outros meios. Ele o faz organizando sua produção como uma atividade complementar da produção direta de seus meios de vida. A isso chamo de economia de excedentes para diferençá-la de mera economia de subsistência. Nela o excedente já aparece como tal na própria produção. O essencial nessa interpretação é que os meios de vida do agricultor não são imediatamente estabelecidos pela mediação do mercado. Mesmo que o camponês venha a ter que comercializar também parte de seus meios de vida, ele sabe que está vendendo aquilo que originariamente fora destinado à sua subsistência. É diferente da situação do assalariado e mesmo do pequeno agricultor capitalista que, no momento da produção, não sabe e não pode distinguir entre o que vai constituir seus meios de vida e o que vai constituir o excedente apropriado pelo capital, num caso, ou destinado à sua própria acumulação, no outro. O excedente do camponês da frente de expansão é um excedente concreto, produto de trabalho concreto, do mesmo modo que seus meios de vida. Os meios de vida de quem trabalha para o capital, como ocorre com o operário ou o assalariado do campo, tem seu montante definido pela mediação do capital e é materialização de trabalho abstrato e, portanto, social. Não é o próprio trabalhador que calcula e define quanto da produção vai se constituir em seus meios de vida.

Muitas ressalvas tem sido equivocamente apresentadas a essa concepção. Há, freqüentemente, situações concretas em que, embora o agricultor produza de fato seus próprios meios de vida, toda sua atividade está 
Ancoradouro no rio Xingu, em Altamira, infraestrutura viária da antiga frente de expansão revitalizada pela frente pioneira (1985). dominada pela produção do excedente comercializável. E mesmo que não esteja, seu estado de pobreza o leva freqüientemente a reter para sua subsistência e de sua família, o que sobra do que foi obrigado a vender ao comerciante e intermediário. Não raro tendo que endividar-se junto ao armazém para assegurar a sobrevivência de sua família durante o ano, vendendo antecipadamente a colheita que ainda não fez, do produto que ainda não está maduro. Ao invés de

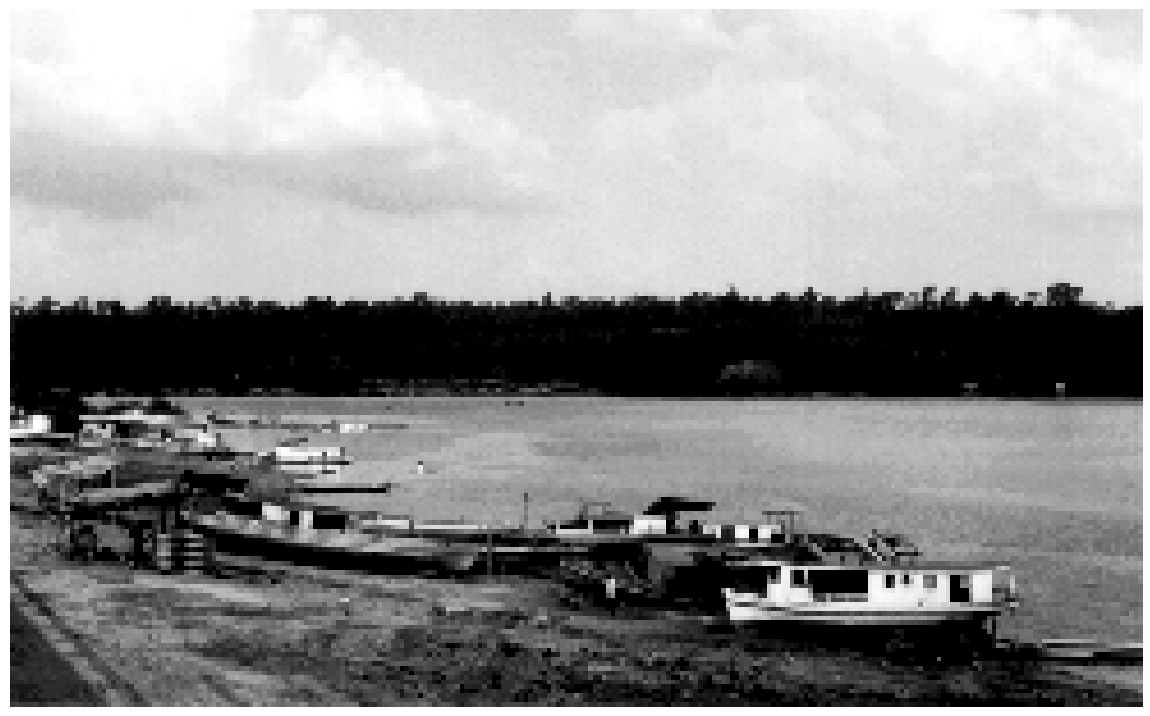

vender a sobra previamente calculada da produção direta de seus meios de vida. Portanto, aparentemente não estaríamos aí em face de uma economia de excedentes, mas de uma autêntica economia de mercado.

As coisas, porém, não são assim. $O$ excedente não é o resto ou a sobra $^{42}$. Não se trata de que o agricultor assegure para si e sua casa a subsistência e só depois venda o que sobrou. Trata-se de uma economia de excedentes porque o raciocínio que preside a organização da produção, isto é, o que plantar e sobretudo quanto plantar e até onde plantar está organizado a partir da idéia de que do que se planta uma parte deveria destinar-se primeiramente à subsistência da família do produtor e um excedente deveria ser produzido para troca ou comércio. $\mathrm{O}$ acréscimo no tamanho da roça em relação à subsistência depende da disponibilidade de força de trabalho familiar ou da possibilidade de pagar a terceiros para que a façam. Essa é uma das razões pelas quais a saída de casa do filho homem e adulto acarreta em geral uma redução nas condições de vida da família, um certo empobrecimento ${ }^{43}$. O excedente depende de vários fatores. De um lado, do número de braços na família. De outro lado, da fertilidade remanescente do terreno. Como em geral na frente de expansão o que se pratica é agricultura de roça, há sempre necessidade de novas terras (e, portanto, de paulatino deslocamento dos agricultores em direção a terras virgens). Mas, depende, também, de que não ocorra uma doença na família, pois isso geralmente implica em despesas extraordinárias com remédios. O que muitas vezes leva a comercializar o 
produto destinado à própria subsistência e ao endividamento posterior para repô-lo quando se fizer necessário. Situação que se repete quando algum desastre natural reduz a produtividade do trabalho, como chuvas excessivas ou seca.

Muitas das dificuldades para compreender as peculiaridades e os efeitos dessa economia simples vêm de pesquisadores que limitaram suas observações, quando as fizeram, a regiões em que a economia camponesa está em crise, sobretudo em consequiência da sua maior dependência do mercado devido a alterações nas necessidades da família camponesa, quando a desorganização da economia de excedentes já está adiantada. E sobretudo em regiões em que as roças camponesas já estão cercadas pelas grandes fazendas de gado. Os camponeses não podem, por isso, concretizar o deslocamento cíclico de suas roças para áreas de mata próximas e terras virgens. O declínio da produtividade agrícola e o que é, de certo modo, seu confinamento, comprometem a reprodução desse campesinato e a dinâmica da frente de expansão.

Mesmo que tais populações se tornem acentuadamente dependentes do mercado e dos pequenos comerciantes de seus povoados, seu vínculo mercantil será acessório, limitado e marginal, no sentido de que não é ele que organiza a totalidade do mundo camponês. Em seu mundo, o mercado é constituído pelos precários terminais de uma rede de aquisição de produtos agrícolas ou extrativos, adquiridos basicamente em troca de outros produtos, sobretudo industrializados, que chegam ao camponês por preços várias vezes multiplicados em relação aos grandes centros urbanos. Isso, porém, não quer dizer que, ao mesmo tempo, os comerciantes de povoado não constituam parte integrante e, mesmo, essencial desse mundo, como de fato constituem (cf. Keller, 1975, p. 681). Porém, os produtos não circulam de modo autenticamente mercantil, até por que tem aí escassa presença o dinheiro, predominando as trocas $^{44}$. Seus preços não refletem o mercado, mas as condições monopolistas da comercialização e, sobretudo, o poder pessoal do comerciante. No geral, a troca se dá no interior de uma relação que é sobretudo patriarcal relação de dominação. Estamos, portanto, em face de uma inserção imperfeita do camponês no mercado porque é imperfeito e não-capitalista o mercado que chega até ele e que procura envolvê-lo em sua teia de exploração econômica. Essa é a forma da conversão, pelo capital comercial e usurário, do excedente físico em lucro.

A frente de expansão não tem sido apenas constituída pelo campesinato. Nela, há uma grande diversidade de personagens, atividades econômicas e relações sociais específicas. Há uma espécie de burguesia de fronteira que muitas vezes toma a iniciativa pela expansão desses modos marginais de produção das mercadorias. Ela é responsável pela implantação desses terminais de sucção de produtos e desproporcional distribuição de mercadorias trazidas de fora.

A frente de expansão está mais próxima das relações servis de trabalho do que das relações propriamente capitalistas de produção. Os casos 


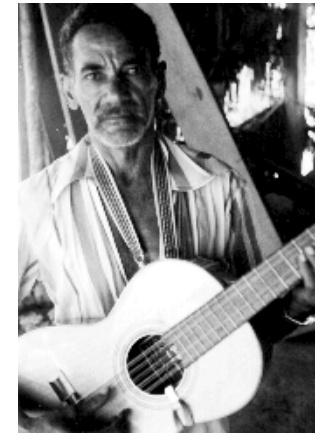

Violeiro que cantou a saga dos posseiros do povoado de Sta. Terezinha, norte do Mato Grosso, em conflito com a nova fazenda de um banco paulista (1979). de peonagem ou escravidão por dívida, no Brasil, ocorrem com muito mais frequiência na frente de expansão do que nas outras regiões. É evidente que são relações produzidas no processo de reprodução ampliada do capital, que recorre a mecanismos de acumulação primitiva em certos momentos dessa reprodução ampliada (cf. Martins, 1995, p. 1-25), isto é, recorre seja ao confisco de bens, como a terra, seja ao confisco de tempo de trabalho mediante ampliação da margem de trabalho não pago.

Tem sido característico da frente de expansão, no Brasil, a ausência da propriedade formal da terra, esta última constituída de simultâneos direitos de posse e domínio. A população camponesa é geralmente posseira ou ocupante de terra, sem título de propriedade. Os patrões, onde os há, foram durante longo tempo, até há poucos anos, ou meros posseiros, como os camponeses, ou arrendatários de terras públicas, pagando ao Estado foros quase simbólicos e, sobretudo, pagando com favores políticos e eleitorais, de tipo clientelista, as concessões territoriais recebidas (cf. Emmi, 1988, p. 92-93). Essa precária relação de pobres e ricos com a posse da terra na frente de expansão não é só resultado da precária institucionalização do direito de propriedade, mas também resultado de que tais territórios estão fora do circuito rentável da renda da terra ou da aplicação de capital na aquisição de terrenos.

Se na frente pioneira a racionalidade econômica e a constituição formal e institucional das mediações políticas estão visivelmente presentes em todos os lugares e momentos, já na frente de expansão é notório o predomínio dos valores sociais, das crenças, do imaginário na formação, definição e sustentação dos vínculos sociais. Aí com frequiência os instrumentos da economia mercantil, especialmente o dinheiro, chegam como expressão do mal e do diabólico. O que se explica porque nela o poder de corrosão dos processos econômicos é extremamente mediatizado, não atua diretamente e imediatamente sobre mentes e relações sociais. No meu modo de ver, isso está relacionado com a produção direta de meios de vida e a produção complementar (mesmo que em primeiro lugar) de excedentes para escambo e comércio. $\mathrm{O}$ dinheiro e a mercadoria não são direta e predominantemente responsáveis pela reprodução social. E, nesse caso, quanto mais é marginal e, ao mesmo tempo, corrosiva e violenta a inserção no mercado, mais se acentua a força do imaginário no modo de vida dessas populações e na tentativa de compreensão de seus próprios dramas e misérias.

Nesse sentido, não se pode compreender a frente de expansão reduzindo-a à expressão material de simples busca de terra por parte dos camponeses pobres expulsos das áreas de latifúndio, sobretudo no nordeste. Essa busca não raro precede o próprio ato de expulsão ou, então, quando o sucede, tem características muito diversas da de uma súbita desagregação de vizinhança. Ela tende a se definir no ambiente do ajustamento precário a uma nova situação decorrente da expulsão, a um novo relacionamento do homem com a natureza, freqüentemente envolvendo perda cultural, realidades novas que impõem redefinição de costumes e tradições. Sobretudo porque essas 
mudanças acarretam desagregação de grupos de constituição antiga, no mais das vezes apoiados numa estrutura de vínculos de parentesco real ou ritual. Uma certa consciência de proximidade do fim dos tempos, decorrente de uma sensação de inexplicável de-moralização, privação, provação e castigo impõe às vítimas da expropriação material e cultural uma certa compreensão apocalíptica dos acontecimentos ${ }^{45}$.

A busca tem um forte caráter comunitário, o que se vê claramente nos locais de imigração ao longo do Tocantins e do Araguaia e mesmo em Rondônia. Em parte porque esses grupos são constituídos por extensas parentelas, agregando ascendentes, descendentes e colaterais, grupos que mesmo uma dramática adversidade econômica não destrói. Um certo simplismo economicista sugere que a expropriação produz mecanicamente a individualização e a integração no mercado de trabalho, já não mais do grupo, mas de cada um de seus antigos membros. No entanto, as evidências mostram que mesmo quando, aparentemente, as coisas ocorrem desse modo, com as migrações para as grandes cidades, o que temos é o contrário: migrações temporárias em grupo dão lugar a migrações definitivas feitas aos poucos, geralmente começando pelos mais jovens, depois os homens e finalmente a família toda. A migração dos membros de uma família tende a durar muitos anos, até que todos se transportem de um lugar a outro ${ }^{46}$. Em parte, tanto num caso quanto noutro, porque esses grupos se concebem como comunidades de destino e de pertencimento. De certo modo, da mesmo maneira que para as populações indígenas, esse pertencimento inclui os ancestrais. A insistência com que algumas tribos tentam recuperar terras ancestrais, como é o caso dos Xavante, tem a ver, em parte, com a localização de seus cemitérios. O sentido do dilaceramento que a destruição desse mundo desperta no íntimo de muitos camponeses da frente de expansão pode ter uma intensidade dramática de difícil identificação a partir de esquemas convencionais de participação.

A história das frentes de expansão no Brasil, neste século, inclusive no sul, tem sido ao mesmo tempo a história do milenarismo camponês ${ }^{47}$. Praticamente todos os movimentos milenaristas ou messiânicos do período ocorreram nas frentes de expansão, ou em bolsões de tradicionalismo em que o modo de vida é idêntico ao que pode ser observado naquelas, e ocorreram nos momentos em que os camponeses estavam sendo expulsos da terra ou estavam ameaçados de expulsão.

Pude observar diretamente que as migrações espontâneas do nordeste para a Amazônia, para um número muito grande de pessoas, estão motivadas por concepções milenaristas. Em diferentes pontos de uma extensão de cerca de oitocentos quilômetros ao longo do rio Araguaia encontrei diversos grupos de camponeses que chegaram à região inspirados pelas profecias do Padre Cícero sobre a existência de um lugar mítico depois da travessia do grande rio. E tive notícia de um grupo desgarrado, empenhado na mesma busca, que se estabelecera à beira do rio Tocantins. Esse lugar mítico é reconhecido como o lugar das Bandeiras Verdes, que ninguém sabe dizer exatamente o que é 
nem onde é. Mas, seria reconhecido quando fosse encontrado, por ser um lugar de refrigério, de águas abundantes, de terras livres, em contraste com o nordeste árido e latifundista ${ }^{48}$.

Trata-se, claramente, de milenarismo medieval e europeu, como é próprio da maioria dos casos de milenarismo no Brasil. Os que procuram as Bandeiras Verdes andam em grupos. Geralmente são grupos de parentes e vizinhos no local de origem. Sua trajetória dos pontos de origem no nordeste aos lugares em que se estabeleceram varia de seiscentos a oitocentos quilômetros. $\mathrm{O}$ deslocamento é lento, em vários casos tomando dos peregrinos muitos anos, com paradas demoradas ao longo do trajeto. O fenômeno vem ocorrendo há uns quarenta anos aproximadamente e se tornou muito intenso nos anos 70 .

É extremamente significativo que os peregrinos se desloquem na direção leste-oeste, que é a mesma direção do deslocamento da fronteira e do movimento de efetiva ocupação do território. Geralmente seguem o sentido de orientação da Via Láctea, a que chamam de Caminho de São Tiago. Lembro aqui que São Tiago é o mesmo Saint Jacques que dá nome às jacqueries, às revoltas camponesas. E o Caminho de São Tiago é o mesmo Caminho de Santiago de Compostela, na Espanha, seguido pelos peregrinos que no tempo das Cruzadas partiam para a Terra Santa, para a guerra contra os infiéis e para resgatar o túmulo de Cristo. Nesse sentido, o deslocamento atual, na direção supostamente indicada pela Via Láctea, segue um rumo oposto ao do percorrido pelos cruzados na Idade Média européia. Lembro, também, que Compostela é “campo de estrelas", isto é, a Via Láctea. Portanto, na fronteira, há um imaginário místico, que mescla e adapta ao sentido de movimento próprio da frente de expansão, vários e diferentes componentes do imaginário medieval. Pode-se dizer que "adapta" na medida em que a realidade que sustentava esse imaginário, na origem, era a do movimento do oeste em direção a leste. Aqui é o contrário, como se os camponeses recorressem ao que parece ser o arquétipo do confronto com o desconhecido, com a natureza, com o outro e, sobretudo, com o próprio limite do humano.

Há um certo componente de guerra santa nesse universo, como ocorreu numa frente de expansão do sul do país, de 1912 a 1916, quando houve a chamada Guerra do Contestado ${ }^{49}$. É como se a humanização do homem tivesse em qualquer circunstância a dimensão de uma peleja mortal, não só entre Deus e o diabo, mas entre o humano e o inumano. As influências das heresias medievais se anunciam através das inversões das relações sociais: é nos opostos que está o sentido do que aparentemente perdeu o sentido. No Contestado, era preciso morrer para renascer no exército divino de São Sebastião; os velhos deveriam se tornar jovens, a sabedoria e o poder estavam com as crianças. Além disso, quem não se recolhesse aos redutos santos era inimigo.

Além dos seguidores da Bandeira Verde, há outros grupos de camponeses peregrinos como o de Maria da Praia, que há muitos anos se desloca de Minas Gerais, no sudeste, para o Norte. Depois de alguns anos atravessando Goiás e Mato Grosso, o grupo se encontra hoje no Pará ${ }^{50}$. 
Na frente de expansão do Vale do Rio Doce, em Minas Gerais, em 1955, o milenarismo de um pequeno grupo de camponeses assumiu a forma de alucinação coletiva e durou uns poucos dias. Aí também a inversão se deu pela troca de nomes das pessoas, pelo recebimento de um novo nome. Ao mesmo tempo, promoveu a configuração do inimigo: os possuídos pelo demônio (cf. Castaldi, 1957, p. 17-130).

Há muitas indicações de joaquimismo nesses movimentos, inclusive nos recentes, na Amazônia. Isto é, aparentemente há influências das idéias de Gioacchino Da Fiore, um monge calabrês do século XII, responsável pela elaboração e difusão de concepções relativas à chegada do Tempo do Espírito Santo $^{51}$. A utopia joaquimita se manifesta, no milenarismo sertanejo, nas práticas comunitárias, já que sua previsão é a de que há de chegar um tempo de justiça, de fraternidade, de liberdade, de fartura - um tempo de libertação.

Têm sido muito fortes na região as representações do mal que aflige os camponeses ameaçados de expulsão da terra pelos grandes proprietários e pelas grandes companhias na figura da Besta-fera apocalíptica. Freqüentemente, os diferentes, os de fora, os antagônicos, são considerados "correios da Besta”, enviados da Besta. A Besta é também a configuração do dinheiro nesse universo marcado pelo grande fluxo do capital, agente reconhecido das violências contra esses camponeses ${ }^{52}$.

Também entre as populações indígenas na situação de contato têm ocorrido movimentos messiânicos no período relativamente recente, como entre os Tükuna, os Ramkokamekra-Canela, os Krahô e diferentes grupos Tupi ${ }^{53}$. Freqüentemente, concepções messiânicas relacionadas com a proximidade do branco e a desorganização do mundo tribal que ela acarreta. Baseiam-se, quase sempre, na alteridade que o branco representa, na desigualdade de forças no confronto entre índios e brancos. Se são tentativas de incorporar os brancos nas suas referências míticas, são também construções míticas da inversão possível dessas relações, como ocorreu no messianismo Krahô.

O reavivamento, entre os civilizados, de concepções arquetípicas, de origem medieval, na frente de expansão, parece indicar, em termos muito gerais, uma certa dificuldade para elaborar uma consciência própria dos conflitos e da desagregação das relações sociais, sobretudo as relações de parentesco e vizinhança, na situação singular que ali se constitui.

Os desencontros próprios da frente de expansão envolvem consequiências e elaborações muito mais profundas do que ocorreria se os camponeses que nela se encontram apenas estivessem buscando terra ou se os índios apenas estivessem tentando reter ou ampliar seu território. Eles estão, certamente, também buscando terra para trabalhar e assegurar a sobrevivência e a continuidade da família ou tentando manter territórios revestidos de uma certa sacralidade na memória tribal. Mas, o fato de que se encontrem numa situação que é também limite do humano, fronteira de humanidade, limite e fim de mundo, parece impor-lhes a necessidade de deslocar para imaginários mais profundamente estabelecidos a busca de sentido para a vida nos confins 
do humano, na fronteira. A revitalização do imaginário medieval e de um imaginário milenarista e cristão, inclusive, direta ou indiretamente, em alguns grupos indígenas, repõe um sistema de referência também baseado na idéia de limite e fronteira: o confronto entre cristãos e infiéis, entre o bem e o mal. Eles estão, sim, buscando a Terra Prometida, que é muito mais do que o instrumento material da produção que domina o interesse dos pesquisadores e suas análises da frente de expansão. Nesse sonho se manifesta a grande transfiguração produzida pela fronteira, de certo modo definidora da sua singularidade temporária e histórica: tempo e espaço se fundem no espaço limite concebido ao mesmo tempo como tempo limite. É no fim que está propriamente o começo.

Recebido para publicação em outubro/1995

\section{UNITERMS: \\ frontier, historical period, frontier period, social movements, peonage, expansion frontier, pioneer frontier.}

\begin{abstract}
The Frontier is a recurrent theme in the Brazilian literature on Social Sciences. Despite attemps by certain anthropologists in importing notions which F. Turner developed for explaining the expanding frontier of the USA, and which deal with the influence of the frontier on the constitution of American national character, strictly speaking such notions do not apply to the Brazilian case. Geographers and anthropologists, in the period extending from the 30's to the 50's carried out field surveys which provided essential elements for a sociological concept of the frontier as rooted in what is historically unique and sociologically relevant for the Brazilian case. Based on these references, the author puts forth his thesis suggesting that the frontier is, at once, the site of otherness and the expression of contemporaneity of historical epochs. It is here that the unity of the diverse, a methodological presupposition of dialectics, offers the most appropriate and rewarding space for scientifc investigation.
\end{abstract}

\section{Notas}

\footnotetext{
${ }^{1}$ No meu modo de ver, é o caso do útil estudo da economista Leonarda Musumeci, O Mito da Terra Liberta (Colonização 'espontânea', campesinato e patronagem na Amazônia Oriental) (1988). Apesar de seu estudo se referir a um único povoado camponês do Maranhão, em que já não há senão remanescentes sociais da situação de fronteira, a autora o toma como típico da ampla e diversificada situação de fronteira e questiona desenvolta e fartamente interpretações relativas ao tema, que têm como referência um âmbito mais amplo e complexo. Além disso, não se baseia em observações propriamente etnográficas, mas em opiniões de seus entrevistados, freqüentemente induzidas para testar os antagonismos de sua polêmica teórica. Como se as questões propriamente interpretativas
} 
MARTINS, José de Souza. 0 tempo da fronteira. Retorno à controvérsia sobre o tempo histórico da frente de expansão e da frente pioneira. Tempo Social; Rev. Sociol. USP, S. Paulo, 8(1): 25-70, maio de 1996.

pudessem e devessem ser verificadas no terreno do senso comum. Dentre os exemplos de resposta induzida que podem ser encontrados no referido livro, transcrevo este: "P(esquisadora) - '...se alguém tem um terreno sem nenhuma benfeitoria [grifo meu, JSM] e tá querendo ir embora, ele também pode vender?' I(informante) - 'Vende o direito, viu? É mais barato, viu?, mas vende. ' $P$ - 'Mas aí ele tá vendendo o quê?' I - 'Ele tá vendendo só um direito, porque tava trabalhando naquele terreno, e sempre domina. $\mathrm{O}$ cabra vai lá, fala pra botar uma roça, ele diz: 'não, isso aqui é meu', e tal, o povo respeita, viu? Aí ele quer sair...' $P$ - 'O que é dele? Quando ele diz 'isso aqui é meu', o que que é? A capoeira?' I - 'É, só mesmo a capoeira, só o direito, porque trabalha naquele lugar. (...) Porque tem..., trabalha naquele pedaço de chão, aí acha que tem direito, né?, de ninguém entrar ali sem a pessoa comprar'. P - 'Aí são duas coisas que podem ser vendidas: uma é a benfeitoria e outra é o direito, são duas coisas diferentes, né?' [sugere Musumeci, como se não tivesse excluído a benfeitoria na pergunta inicial, JSM]. I - 'Pois é. . . Mas a benfeitoria que a gente fala aqui é o mesmo... é o direito [corrige o informante, reagindo à sugestão de Musumeci, JSM]. É, tá certo, a benfeitoria. Porque quando tem a benfeitoria a gente compra mais caro, né? [corrige-se o informante depois de ter sido induzido a confundir o direito sobre a terra gerado pelo trabalho na terra, o desmatamento, com as benfeitorias, JSM]. Agora, só o direito, a gente compra baratinho...' (Lavrador do Barro Vermelho)". E, então, Musumeci conclui, depois de ter sugerido ao trabalhador que direito e benfeitoria são a mesma coisa e depois de ter recebido o esclarecimento de que não são: “... os depoimentos citados (...) sugerem que o direito pode não abarcar apenas o que de concreto se produziu e construiu sobre a terra; pode englobar também um direito de terra, um direito do local, ou seja, um 'poder de monopólio' sobre a parcela assituada e explorada pelo camponês..." [reforça Musumeci, JSM]. Cf. Musumeci (1988, p. 6869, grifos do original). Assim, Musumeci reduz (e desfigura) a especificidade histórica do direito gerado pelo trabalho na terra de posse ao direito dominante de propriedade enquanto monopólio econômico jurídicamente fundado e assegurado sobre uma parcela de terra. A autora nesse caso procura pôr na boca do trabalhador sua própria tese. As concepções desse e de outros entrevistados da autora e de seu orientador, apontado como co-autor (p. 12), invocam concepções do direito sesmarial dos tempos coloniais, com o qual ambos não parecem familiarizados. Sem contar que um antropólogo, mais do que perguntas verbais aos entrevistados, faria demoradas observações de campo para obter, pela via propriamente antropológica, também as informações não verbalizáveis que lhe indicassem quais são na prática (e não na palavra induzida) os costumes dos camponeses utilizados em suas indagações. A deformação metodológica que assinalo no trabalho dessa autora e do co-autor, faz da economista e do antropólogo os heróis-sujeitos da pesquisa. A propósito desse tema, sugiro a leitura do interessante artigo de Paulo Roberto Arruda de Menezes, "A questão do herói-sujeito em cabra marcado para morrer, filme de Eduardo Coutinho" (1995, p. 107-206).

${ }^{2}$ Godfrey, que é geógrafo, menciona esse fato expressamente em relação ao Brasil e, ao mesmo tempo, assinala que uma das limitações da interpretação de Turner sobre a fronteira americana é justamente a de ter ignorado a luta pela terra. Cf. Godfrey (1979, p. 8 e 4059). O conflito social, como conceito-guia, é também adotado por Marianne Schmink e Charles H. Wood (1989, p. 14) [Para a versão já publicada desse estudo, cf. Marianne Schmink e Charles H. Wood 1992]. Jean Hébette, numa avaliação dos estudos sobre a fronteira no Brasil, sublinhou que, na atualidade, o conflito pela posse da terra é o tema mais polarizador. Cf. Jean Hébette (1978, p. 3).

${ }^{3}$ Foweraker ressalta que "o antagonismo primário da fronteira reside entre os camponeses e os 'outros'...", no sentido de uma certa diluição da dimensão propriamente de classe do conflito fundiário (1982, p. 48).

${ }^{4} \mathrm{O}$ tema da alteridade, nesse tipo de contato, está proposto no estudo de Todorov sobre a Conquista da América, em que ele trata "da descoberta que o eu faz do outro" e do fato de que "o eu é um outro". Cf. Todorov (1984, p. 5).

${ }^{5} \mathrm{Cf}$. meu ensaio sobre "Antropofagia e barroco na cultura latino-americana" (Martins, 1993, p. 15-26).

${ }^{6}$ Esses caboclos "não são as sentinelas avançadas da marcha para oeste". Cf. Monbeig, (1940, esp. p. 111; 1952; 1957).

${ }^{7}$ Há diferenças, também, no modo de ver a fronteira quando se faz a comparação entre 
países diferentes. Gerhard seleciona como principais traços para um estudo comparativo de fronteiras a democracia política na forma de auto-governo, a tendência ao igualitarismo, a mobilidade e a conseqüente quebra do vínculo do costume ou da tradição. Cf. Gerhard (1959, p. 207). Os estudos da situação de fronteira no Brasil indicam que os traços relevantes são aqui inteiramente outros, em geral opostos a esses.

${ }^{8}$ Foi uma antropóloga, Gioconda Mussolini, que chamou a atenção dos cientistas sociais brasileiros para o fato de que os nossos antropólogos e sociólogos, até os anos 50, optaram pela realização de estudos de comunidade nas "zonas velhas", isto é, em zonas tradicionais e socialmente estáveis, em oposição às "zonas novas" ou pioneiras. Nesse sentido, "não têm se interessado pela zona pioneira", ou seja, pelas zonas de organização social ainda instável. Ela sugere, assim, as implicações dessa opção: "Quase que invariavelmente, porém, os estudos de comunidade realizados no Brasil revelam, como dissemos, interesse definido da parte de seus autores por áreas nas quais se espera verificar a qualidade de 'organização cultural' e estabilidade social, selecionando-se, por esta razão, pontos que além de situados nas 'zonas velhas' de povoamento, sejam o suficiente isolados para que se anteveja a possibilidade de concretização daquela expectativa. " Cf. Mussolini (1955, esp. p. 338, grifo meu). Portanto, o que o pesquisador via e vê em seu trabalho de campo está acentuado por essa opção e por essa orientação prévias.

${ }^{9}$ Embora eu mesmo, neste texto, use o conceito de capitalismo várias vezes, faço-o, porém, sabendo que introduz uma distorção na concepção marxiana de capital e de modo capitalista de produção. $\mathrm{O}$ conceito de capitalismo, que Marx não usou, sugere um sistema, idéia muito distante do que o próprio Marx pensava, pois sua referência era o processo do capital, o movimento do capital, sua reprodução ampliada e não sua mera reprodução. Faço-o, porém, para facilitar o diálogo crítico que este texto contém, sobretudo com autores que trabalham com a pressuposição de um sistema social, em cujo interior o progresso é um desdobramento da ordem, à moda positivista.

${ }^{10}$ No mesmo número da revista em que Cardoso de Oliveira publicou seu artigo e projeto de pesquisa, seu aluno Otávio Guilherme C. A. Velho publicou um relatório de trabalho de campo, em princípio norteado por aquele mesmo projeto, em que seu autor diz: "O dinamismo da frente hoje está intimamente ligado à busca de terra”. (Cf. Velho, 1967, p. 38). Essa afirmação poderia ter diferentes sentidos, mas a ênfase geral do artigo é posta nos aspectos propriamente econômicos da frente de expansão. É aí que nasce, no meu modo de ver, a reorientação reducionista dos estudos antropológicos da frente de expansão na perspectiva do que os geógrafos definiram como frente pioneira, dominados pelas questões econômicas, como se veria no primeiro livro do autor sobre o tema (cf. Velho, 1972). Nessa orientação, a questão da centralidade do conflito, que motiva Cardoso de Oliveira, vai para um plano inteiramente secundário, embora Velho tenha dito no referido artigo, que seu trabalho "pretende ser um desdobramento do artigo de Roberto Cardoso de Oliveira..."(p. 29).

${ }^{11}$ Falando da frente pioneira em São Paulo, Monbeig esclarece que "os pioneiros paulistas jamais puderam dispor de terras gratuitas: nada é mais estranho à faixa pioneira brasileira que a 'terra devoluta'. (...) A posse do solo começa por um negócio..." (cf. Monbeig 1957, p. 110).

${ }^{12}$ Cf. Neiva, (1949, p. 226). A distinção entre fronteiras políticas e fronteiras econômicas estava claramente presente no discurso geo-político do Estado Novo, que justificava a Marcha para Oeste. O presidente Getúlio Vargas referiu-se a elas, em sua viagem à Amazônia, em 1945, no documento relativo à fixação do primeiro marco da estrada para o Xingu e lugar da futura cidade de Xavantina. Nesse documento, Vargas assinala a nova consigna da frente pioneira apoiada nas pressões e nos favores do Estado: fazer coincidir as duas fronteiras. Concretamente, isso indicava a aceleração do avanço da frente pioneira sobre a faixa da frente de expansão (cf. Cunha, 1974, p. 119).

13 “São etapas sucessivas de penetração civilizadora e, conseqüentemente, correspondem a graus diversos de intensidade de interação. Assim, as frentes extrativas são freqüientemente penetrações exploratórias e recentes a que se seguirá a ocupação definitiva de base agrícola. Esta última raras vezes assumiu no Brasil a forma de fronteira de expansão sobre áreas indevassadas. Via de regra, cresce sobre regiões previamente exploradas por coletores de artigos florestais" (Ribeiro, 1977, p. 244).

${ }^{14}$ Apoio-me, nessa orientação metodológica, em dois trabalhos fundamentais de Henri 
MARTINS, José de Souza. 0 tempo da fronteira. Retorno à controvérsia sobre o tempo histórico da frente de expansão e da frente pioneira. Tempo Social; Rev. Sociol. USP, S. Paulo, 8(1): 25-70, maio de 1996.

Lefebvre (cf. 1949, p. 78-100; 1953, p. 122-140). Esses dois trabalhos estão traduzidos para o português (cf. Martins (org.), 1981, p. 144-177). Sartre reconheceu e destacou a fundamental importância metodológica do segundo artigo "em todos os domínios da antropologia" (cf. Sartre, 1966, esp. p. 46-47).

${ }^{15}$ A junção e o confronto das duas concepções - frente de expansão e frente pioneira -, como momentos históricos distintos e combinados de diferentes modalidades da expansão territorial do capital, foi feita pela primeira vez numa pequena comunicação que apresentei, em julho de 1971, na Reunião Anual da Sociedade Brasileira para o Progresso da Ciência, em Curitiba (PR). Essa comunicação, por iniciativa do prof. José Roberto do Amaral Lapa, foi publicada no mesmo ano em Estudos Históricos (1971, p. 33-41). Foi reproduzida, em 1972, em Cadernos (1972, p. 102-112) e, em 1973, na Revista Mexicana de Sociologia (Vol. XXXV, ${ }^{\circ}$. 4). Reeditei-a no meu livro Capitalismo e Tradicionalismo - Estudos sobre as contradições da sociedade agrária no Brasil (1975, p. 43-50). Nessa perspectiva, teve ampla repercussão entre os estudiosos do tema e é hoje referência corrente em muitos estudos sobre a fronteira. Especialmente os trabalhos sobre temas históricos destacaram o acerto de tratar as duas concepções como expressões de um mesmo processo. Dentre os estudos amplamente influenciados por aquele texto de 1971 e pela orientação que nele propus, destaco em particular os de Warren Dean (1976); de Joe Foweraker (1981); e de Carlos Rodrigues Brandão (1983).

${ }^{16}$ A concepção articulacionista é proposta por Pierre-Philippe Rey (1976).

${ }^{17}$ Bogue fala em sociedades de fronteira (cf. Bogue, 1968, p. 75).

${ }^{18}$ Este artigo estava pronto há vários meses quando os jornais de setembro e outubro de 1995 noticiaram o encontro de dois grupos indígenas desconhecidos, ocorrido em Corumbiara, Rondônia. No dia 3 de setembro, um domingo, depois de quatro dias de busca, uma equipe dirigida pelo sertanista Marcelo Santos, chefe do Departamento de Índios Isolados de Rondônia, da Fundação Nacional do Índio (Funai), encontrou um casal de índios não identificados. A primeira palavra que o sertanista dirigiu ao casal, num português não compreendido, foi "amigo". Só quando armas e equipamentos foram depositados no chão, porém, é que o casal então compreendeu que a intenção era de paz. Transcrevo o relato do jornalista sobre esse momento solene e litúrgico: "Os primeiros passos do casal foram vagarosos. Desceram até a ponte de madeira sobre o riacho que separa a aldeia da mata. Antes de atravessar, a mulher iniciou uma cerimônia. Parecia pegar no ar os maus espíritos e assoprar para longe, para dentro da mata. O grupo visitante permaneceu quieto até que se aproximassem. A primeira reação dos dois foi tocar braços e mãos dos brancos. 'Querem sentir se estamos nervosos', disse Marcelo. A mulher tremia. O homem balbuciava um som ininteligível. Marcelo tocou-lhes os adornos, repetiu 'amigo, amigo' e sorriu. A forma de entendimento mais eficaz entre os dois grupos foi, afinal, a mais simples: o riso" (cf. Pereira, 1995a, p. 15). O sertanista encontrara vestígios desse grupo já em 1985. No início de outubro, o lingüista Nílson Gaba Jr. , do Museu Paraense Emílio Goeldi, identificou a língua falada pelos índios como canoê, "encontrada apenas entre seis pessoas na Área Indígena Guaporé, também em Rondônia" (cf. $O$ Estado de S. Paulo, 10/10/1995, p. A16). Até o momento, foram localizadas na área do contacto quatro pessoas pertencentes à etnia canoê. Um novo grupo, de sete pessoas, encontrado na segunda quinzena de outubro não é canoê. Aparentemente, pertence à etnia macurape (cf. Pereira, 1995b, p. A14).

${ }^{19}$ A história do contacto com os índios Kreenakarore e suas consequiências dramáticas foi contada no noticiário jornalístico que o narrou quase que diariamente de 1972 a 1975. Cf. , especialmente, O Estado de S. Paulo (8/12/1972, p. 10); O Estado de S. Paulo (12/ 12/1972, p. 19); O Estado de S. Paulo (31/12/1972, p. 27); Coojornal, $\mathrm{n}^{\circ} 59$ (11/1980, p. 16); O Estado de S. Paulo (15/01/1975, p. 15); O Estado de S. Paulo (17/08/1975, p. 27).

${ }^{20}$ São pelo menos das seguintes tribos os grupos atraídos e contactados nesse período, na região amazônica: Arara, Ararapé, Aua-guajá, Avá-canoeiro, Buré, Cinta-larga, Guajá, Ipixuna, Kanamari, Koxodoá, Kreenakarore, Kulina, Kuruayá, Maniteri, Marubo, Mayá, Mayoruna, Munkü, Nambikuara, Nereyo, Parakanã, Suruí, Tükuna, Txikão, Txukahamãe, Uru-eu-wau-wau, Urupá-kwine, Wai-wai, Waiãpi, Waiká, Waimiri-Atruahi, Yanomami, Yauri e Zoró.

${ }^{21}$ A propósito da designação de caboclo no caso dos índios Tükuna do Alto Solimões, Roberto Cardoso de Oliveira nos dá uma explicação fundamental: "o caboclo pode ser 
visto ainda como o resultado da interiorização do mundo do branco pelo Tükuna, dividida que está sua consciência em duas: uma voltada para os seus ancestrais, outra para os poderosos homens que os circundam. O caboclo é, assim, o Tükuna vendo-se a si mesmo com os olhos do branco; isto é, como intruso, indolente, traiçoeiro, enfim como alguém cujo único destino é trabalhar para o branco" (Oliveira, 1964, p. 80). Darcy Ribeiro também observou que "o índio aprendeu a se olhar com os olhos do branco, a considerarse um pária, um bicho ignorante, cujas tradições mais veneradas não passam de tolices ou heresias que devem ser erradicadas" (Ribeiro, 1977, p. 213).

${ }^{22}$ Las Casas registrou a mesma concepção no vale do Tapajós (cf. 1964, p. 17). Dom Eurico Kräutler, que foi missionário e, depois, bispo na região do Xingu, de 1934 a 1965, registra em suas memórias: "Muitos seringueiros tem desprezo pelos índios. Dizem que é permitido matá-los, porque são animais ferozes e não gente” (Kräutler, 1979, p. 17), “... tenho um filho de alguns meses de idade. Vim buscar o senhor para batizá-lo. Quero que ele se torne cristão. Nos arredores rastejam as bestas. - Na sua linguagem, 'bestas' queria dizer 'índios'” (p. 72). Referindo-se a Judite, que fora raptada pelos índios Gorotire e que conseguiu escapar graças à ajuda de Utira, um índio Juruna, também prisioneiro, o autor comenta: "Judite, porém, logo se esqueceu de seu salvador: sendo índio, afinal, ele não passava de um bicho..." (p. 90).

${ }^{23}$ Cf. também Caron (1971, p. 30).

${ }^{24}$ Informação pessoal de Betty Mindlin.

${ }^{25}$ Darcy Ribeiro registra que os Xokleng, do sul do Brasil, também acreditavam que eles é que haviam "amansado" os brancos (cf. Ribeiro, 1977, p. 368).

${ }^{26}$ Ocorrências parecidas se deram no território do atual estado de Rondônia. Empurrados pelos brancos para as serras e cabeceiras dos rios, diferentes grupos indígenas entraram em conflito entre si (cf. Leonel, 1995, passim).

${ }^{27}$ Lux Vidal já havia estudado a relação entre mito e História no caso dos Kayapó-Xikrin (cf. Vidal, 1977).

${ }^{28}$ Em relação aos índios Suruí, Mindlin observou que, quando morre algum deles, queimam as respectivas posses, inclusive vitrola, rádio, gravador, bicicleta, roupas, animais de criação (Mindlin, 1985, p. 146). Também os Terena destroem os bens dos mortos (cf. Oliveira, 1976, p. 106).

${ }^{29}$ Devo essa informação a Hiparidi Dzutsi Wa Top Tiro, índio xavante matriculado como aluno especial no curso de graduação em Ciências Sociais da Faculdade de Filosofia, Letras e Ciências Humanas da Universidade de São Paulo, e Luís Roberto de Paula, aluno do mesmo curso que, como bolsista de iniciação científica, está fazendo estudos sobre os índios Xerente, de Goiás, parentes dos Xavante. Giaccaria e Heide constataram que no século XVIII os Xavante já se encontravam em Goiás, há mais de mil quilômetros do mar. Mas notaram também que os velhos Xavante dizem que sua tribo proveio "do Oriente, do mar". Esses mesmos autores assinalaram que os Xavante "têm uma lembrança muito viva do mar que se encontra em algumas de suas lendas" (cf. 1972, p. 13-14).

${ }^{30}$ No mesmo ano do relato de Baldus, os Tapirapé foram de fato atacados pelos Kayapó (cf. Wagley, 1977, p. 31).

${ }^{31}$ Uma emblemática indicação da interpenetração da frente pioneira com a frente de expansão se deu em 1951. Dois funcionários da Fundação Brasil Central desceram o rio Arinos em direção ao rio Juruena de carona num batelão de um pequeno grupo de seringueiros que ia tentar reabrir seringais na confluência dos dois rios. Um dos funcionários era remanescente da Expedição Roncador-Xingu, que percorrera esse trajeto demarcando locais para futuras cidades, na Marcha para Oeste. Era um agente da frente pioneira. O grupo de seringueiros era remanescente de conflito com os índios da região e tentava reocupar, décadas depois, a terra defendida pelos índios. Era agente da frente de expansão (cf. Cunha, 1974, p. 28-29).

${ }^{32}$ Hébette constatou que a fronteira no Paraná e no Mato Grosso, ocupada nos anos 50 e 60, fechou-se em quinze anos. Em Rondônia, o fechamento se deu em cinco anos (cf. Hébette, 1978 , p. 7). Sobre a intensificação do ritmo das expulsões dos camponeses na região do Xingu, cf. Schmink \& Wood (1992, p. 220). 
${ }^{33}$ Hébette et alii, no seu detalhado relatório sobre a fronteira, assinalam, no início dos anos 70, a migração de grupos numerosos do norte do Espírito Santo e do sul da Bahia, em decorrência do esgotamento do solos e da expansão das famílias, para o Médio Tocantins. Um desses grupos era constituído de cerca de duzentas pessoas lideradas por um fazendeiro e seus agregados (cf. Hébette et alii, 1983, p. 25-28).

${ }^{34}$ Em 1977, quando o conflito fundiário no sul do Pará mal se configurara, Ianni chegou a prever que, diante da aliança entre o capital monopolista e o Estado, "o campesinato pouquíssimo ou nada pode fazer. Cabe-lhe resignar-se à destruição, buscar alguma exígua acomodação ou simplesmente proletarizar-se" (cf. Ianni, 1978, p. 131). No entanto, os camponeses da mesma região que ele estudou e das regiões vizinhas, ao longo destes últimos vinte anos, ao invés de sucumbirem ou de se renderem, vêm demonstrando uma persistente capacidade de resistência à violência dos grandes proprietários de terra (cf. Figueira, 1986 e 1992); e, ainda, Alfredo Wagner B. de Almeida (1980, p. 14). Detalhes dessa resistência na região de Marabá se encontram em Jean Hébette (s/d). Do mesmo modo, catastróficas previsões sobre o fim de grupos indígenas, apesar de graves elevações nos índices de mortalidade e graves efeitos destribalizadores do contacto, não se confirmaram por inteiro. Ao contrário, têm sido vários os casos de vigoroso renascimento de tribos que haviam sido consideradas poucos anos antes em estado terminal. Foi o caso dos índios Parkatejê do Pará. Sobre esse caso, cf. Ferraz (1983). E foi também o caso mais recente dos Waimiri-Atruahi, no Amazonas.

${ }^{35}$ Diferentes pesquisadores têm assinalado conflitos fundiários em áreas em que ainda prevalecem concepções relativas ao que se chamava, no período colonial, terras do comum uso público ou, simplesmente, terras do comum; terras de locais em que as autoridades não podiam conceder datas ou sesmarias. Não eram, propriamente, terras comunais, mas terras destinadas expressamente pelas câmaras ou pela Coroa ao uso comum dos moradores, quando coubesse. Houve áreas em que as terras do comum eram destinadas especialmente aos animais dos tropeiros, como houve áreas que eram destinadas seja à agricultura seja à coleta de produtos vegetais por parte dos que não tivessem outros meios de fazê-lo. Em relação à sobrevivência dessa instituição, cf. Andrade (1981, esp. p. 8-10); Alfredo Wagner Berno de Almeida (1989, p. 163-196). Sonia Lacerda, Eduardo Graziano e Margarida Maria Moura observaram no Jequitinhonha, em Minas Gerais, o costume ancestral da posse em comum das terras de chapada, como contrapartida e complemento da posse privada das grotas ou veredas (cf. Lacerda, 1983; Graziano, 1982; Moura, 1988, esp. p. 125 ss.). Esse mundo rústico, dotado de lógica própria, sobrevive (e se recria) não só nas frentes de expansão, mas também "em bolsões de resistência (testemunhas vivas de outra época) nos interstícios dos amplos latifúndios" (cf. Cardoso, 1979, p. 92). Além das terras do comum ainda na posse de lavradores que se crêem com direito a seu uso com base no costume, há no Brasil terras legalmente insuscetíveis de apropriação privada, como as terras de marinha e as terras do Distrito Federal, que, devido ao desmantelamento das instituições relativas às terras do comum, estão geralmente na posse de moradores ricos por óbvias razões políticas. Nessas terras, o Estado ainda mantém o domínio, como ocorria no regime sesmarial.

${ }^{36}$ Já em meados dos anos 70, dez anos após o início da política de incentivos fiscais, as grandes empresas davam-se conta de que o mercado internacional de carne, que justificava a política de transformação da floresta em pastagens, não merecia os altos investimentos de seus empreendimentos. A manutenção das fazendas pelos empresários só prosseguiu porque estava apoiada em generosa política de subsídios e incentivos financeiros concedidos pelo governo (cf. Branford \& Glock, 1985, p. 81).

${ }^{37}$ Branford e Glock registram um dos aspectos dessa aceleração: entre 1940 e 1960, as famílias camponesas da fronteira podiam esperar ter que se mover para uma nova terra apenas uma ou duas vezes em sua vida, incluindo aí o deslocamento provocado pela exaustão do solo. Famílias que podiam prever uma ocupação de terra por dez ou vinte anos tem sorte hoje se conseguem ficar em paz por dois ou três anos na mesma terra sem ser expulsas (cf. Branford \& Glock, 1985, p. 123).

${ }^{38}$ Num desses estudos, o autor estima comparativamente o tempo de trabalho socialmente necessário para a produção do arroz em regiões em que essa produção se dá em distintas situações econômicas (eu diria, também, em distintas situações históricas), entre outras, a da agricultura camponesa da fronteira agrícola e a da cultura arrozeira altamente capitalista e moderna do Rio Grande do Sul. Constata que na fronteira é necessário o 
dobro ou pouco mais de dias de trabalho para a produção de uma tonelada do cereal, enquanto que o tempo médio fica próximo do da fronteira. Essa constatação e o comportamento dos preços permitem ao autor concluir que "em relação a produtos camponeses, os preços de mercado estão, em última instância, regulados pelos valores respectivos" (cf. Costa, 1992, p. 181-183). A intenção do autor é a de contestar a suposta tese da funcionalidade capitalista da agricultura familiar e camponesa, que, nos termos de sua crítica, deixa de atribuir a quem a forjou. Como Musumeci, o autor também não se dá conta de que há, no mínimo, duas teses do que foi indevidamente definido como "funcionalidade da agricultura camponesa", bem diferentes entre si: a tese vulgar que considera os excedentes comercializáveis da agricultura familiar como simples sobras da subsistência camponesa e que concorrem diretamente para o barateamente do custo da vida da classe operária (essa tese está reconhecida desse modo em Leonarda Musumeci, 1988, p. 287), e desse modo expressamente formulada por Otávio Guilherme Velho (1972, p. 125); e a tese oposta (equivocamente confundida pelos críticos com a tese vulgar) da integração da produção camponesa, através de uma economia de excedentes, no processo de reprodução do capital [Essa é a tese que sustento (cf. Martins, 1969b, p. 121-145; 1969a, p. 3-16). Cf., também, 1975 (esp. p. 1-50, 57-72 e 103-161); e, ainda, 1986, (esp. cap. 8): "Pequena produção agrícola - antimito da produção capitalista no campo (crítica aos críticos)" (p. 113-152)]. O texto de Costa é indicativo de como alguns estudiosos, ao comparar padrões empresariais e padrões camponeses de produção, reduzem a lógica destes à lógica daqueles. Desse tipo de interpretação desaparecem os componentes propriamente históricos e antropológicos da vida do campesinato de fronteira, isto é, o seu próprio e característico cálculo, como se o camponês da fronteira fosse apenas um capitalista em miniatura.

${ }^{39}$ A frente de expansão é essencialmente um mundo criado pelo modo como se dá a inserção dos trabalhadores rurais, que produzem diretamente seus meios de vida, no processo de reprodução ampliada do capital. Nesse mundo, apesar da determinação capitalista de suas relações sociais, as concepções e valores precedem, na vida de seus membros, os interesses econômicos e a eles se sobrepõem (cf. Martins, 1969a, p. 3-16) [reproduzido em Martins, 1975, esp. p. 12]. Essa formulação ganha sentido neste entendimento mais amplo do problema: "Sob o capitalismo dependente, a persistência de formas econômicas arcaicas não é uma função secundária e suplementar. A exploração dessas formas e sua combinação com outras, mais ou menos modernas e até ultramodernas, fazem parte do 'cálculo capitalista' do agente econômico privilegiado. Por fim, a unificação do todo não se dá (nem poderia dar-se) ao nível da produção" (cf. Fernandes, 1968, p. 65). Embora trate de grupos rurais tradicionais localizados em regiões de ocupação antiga e não na frente de expansão, o artigo de José César Gnaccarini sobre o casamento por rapto na área canavieira de São Paulo é um esclarecedor e bem feito estudo sobre o modo complexo como se combinam as questões econômicas da sobrevivência com as questões sociais da convivência (cf. Gnaccarini, 1971, p. 75-94). Ainda que por vias diversas, tanto a interpretação de Gnaccarini quanto a de Martins se fundam em Antonio Candido (1964, esp. capítulo 17). A propósito desse livro e destacando justamente a questão da resistência (e da persistência cultural), Fernando Henrique Cardoso assinala: "Pois que de crença também se sobrevive"(cf. Cardoso, 1979, p. 98).

${ }^{40}$ Ampla e detalhada formulação teórica sobre a expansão territorial do capital encontra-se em Marx (1959, p. 573-753).

${ }^{41}$ Costa constata que enquanto os modernos empresários do arroz, no Rio Grande do Sul, podem vender seu produto mais barato até a $1.176 \mathrm{~km}$ da sua capital, "a produção da fronteira é colocada com vantagem de preço num raio de $2.324 \mathrm{~km}$ de distância da sua origem" (cf. Costa, 1992, p. 189 - nota).

${ }^{42}$ Musumeci diz, com razão, que "é equivocada a imagem que muitos ainda fazem do lavrador de fronteira como alguém que produz para a subsistência (autoconsumo) da família e comercializa apenas as sobras da sua produção" (cf. Musumeci, 1988, p. 287, grifo do original). Embora não haja citação expressa, sua procedente crítica se dirige a concepções contidas em Otávio Guilherme Velho (1972, esp. p. 67 e 113). Musumeci, porém, ignora que, além dessa definição vulgar de excedente, há propriamente uma definição de economia do excedente por oposição a economia de subsistência, pois é comum o equívoco de confundir a economia camponesa com mera economia de subsistência. A concepção de excedente que ela acertadamente critica é a base da tese da 
MARTINS, José de Souza. 0 tempo da fronteira. Retorno à controvérsia sobre o tempo histórico da frente de expansão e da frente pioneira. Tempo Social; Rev. Sociol. USP, S. Paulo, 8(1): 25-70, maio de 1996.

funcionalidade da agricultura camponesa da fronteira tal como Velho a assume sozinho (p. 125) e que ela também crítica, com integral razão, porém, novamente, sem mencionar o destinatário (cf. Musumeci, p. 296-297).

${ }^{43}$ Em suas atentas observações e demorada permanência no então povoado de Sta. Terezinha, no norte do Mato Grosso, Lisansky assinalou que a organização da produção dos camponeses locais se baseia em avaliações e cálculos quanto à area a ser cultivada, tendo em conta o grau de fertilidade remanescente do terreno, o número de braços disponíveis na família e a quantidade de sacas que poderá ser comercializada depois de separado o arroz destinado à subsistência (cf. Lisansky, 1980, p. 148-149), [para a versão publicada desse trabalho, cf. Lisansky, 1990]. Esse procedimento é comum na frente de expansão. Procedimentos semelhantes foram observados por Luna no Maranhão, que constatou a diminuição do tamanho das roças e da produção de excedentes quando os filhos se tornam adultos e deixam a casa dos pais (cf. Luna, 1983, p. 61).

${ }^{44} \mathrm{Em}$ dois estudos extremos no tempo, separados entre si por cerca de 40 anos, pode-se observar essa persistente característica da fronteira (cf. Galvão, 1976, p. 23 e Luna 1983, p. 62-63)

${ }^{45}$ Foi o que ocorreu no surto milenarista do bairro do Catulé, em Malacacheta, Minas Gerais, em 1955, quando a frente de expansão começou a se esgotar (cf. Castaldi, 1957, p. 17-66; Martins, 1983 , p. 62 e ss.).

${ }^{46}$ Touraine foi o primeiro a observar esse processo no Brasil, confirmado depois por Eunice Durhan (cf. Touraine, 1961, p. 93; Durhan, 1973, p. 132-136).

${ }^{47}$ Gerhard assinala um fenômeno parecido, embora diferente, no Oeste americano: a migração de grupos comunais, sempre de comunidades religiosas. Entretanto, ele não indica a ocorrência de movimentos messiânicos ou milenaristas, o que talvez se explique pelo fato desses grupos serem geralmente grupos protestantes (cf. Gerhard, 1959, p. 220).

${ }^{48}$ A busca das Bandeiras Verdes se mescla com outros milenarismos contemporâneos na região, como o da busca do Paraíso do Divino. Este último, com evidências de inspiração nas heresias de Gioacchino Da Fiore, especialmente no que se refere à negação da unidade da Santíssima Trindade. Sobre esse grupo e essa mescla, cf. Vieira (1981, esp. 63-82). No mapa das migrações das famílias que afinal se aglutinaram em busca da comunidade utópica, Vieira mostra que, apesar de algumas serem originárias do nordeste, e terem vivido depois em São Paulo ou no sul de Goiás, os integrantes do movimento migram do leste para oeste, com ligeira inflexão para o norte (p. 101). Sobre a difusão do joaquimismo em Minas Gerais, Goiás e Mato Grosso, cf. Brandão (1978, p. 64-165 e 142-144).

${ }^{49}$ Cf. Maurício Vinhas de Queiroz (1966); Maria Isaura Pereira de Queiroz (1957); Duglas Teixeira Monteiro (1974); Oswaldo Rodrigues Cabral (1979).

${ }^{50}$ Maria da Praia teria sido originária de Minas Gerais. O grupo se constituiu de umas quinze famílias, que, orientadas por ela, saíram em busca do Bom Lugar. O trajeto dos romeiros em busca dessa terra prometida foi interrompido demoradamente três vezes. A essas interrupções os romeiros chamam de Estações, como na Via Sacra. Nelas, constroem igreja, povoado e abrem roças. Houve três Estações: Boa Esperança, São Miguel e Buriti Alegre. A Quarta Estação seria a Estação da chegada. Maria da Praia morreu na Terceira Estação. Quando o grupo passou pelo sertão de Sta. Terezinha, no norte do Mato Grosso, e ali se fixou por uns tempos, o padre Antonio Canuto, que era pároco do lugar, tomou conhecimento de sua existência. Depois o grupo se deslocou para o estado do Pará, onde se encontra hoje. Canuto realizou minuciosa entrevista, sobre a história e as crenças do grupo, com a filha de Maria da Praia, já no Pará (cf. Canuto, 1975). Maria Antonieta da Costa Vieira vem acompanhando e estudando esse grupo, e suas crenças, que se acha hoje na região do Xingu.

${ }^{51}$ Hennessy já havia observado a relação entre o milenarismo joaquimita e a fronteira no período colonial e entre milenarismo e fronteira no século XIX, na América Latina (cf. Hennessy, 1978, p. 36-38 e 117-120). Sobre Gioacchino e suas idéias há uma vasta literatura européia. Para uma visão abrangente do tema, cf. Antonio Crocco (1976). Movimentos camponeses de inspiração joaquimita direta ou indireta ocorrem até hoje em diferentes sociedades, mesmo em San Giovanni in Fiore, na Calábria, terra de Gioacchino. Lá, a utopia joaquimita foi assimilada pelo Partido Comunista e pelos 
camponeses locais, protagonistas de uma larga história de conflito social motivado pela privação dos usi civici das terras, que lhes haviam sido cedidos desde os tempos do Abade Joaquim (cf. Steinberg, 1981, p. 359-360). Gioacchino influenciou as concepções milenaristas e sebastianistas do Padre Antonio Vieira e está expressamente citado várias vezes no texto sobre a "Duração do 5'. Império", que faz parte da coleção dos documentos arrolados pelo Tribunal da Inquisição, que o condenou em 1667 (cf. Vieira, 1994, p. 177-203).

${ }^{52}$ De um folheto manuscrito recolhido no norte do Mato Grosso, cópia de folheto de cordel impresso, sob o título de $A$ Voz do Padre Cícero, consta a seguinte expressiva estrofe relativa a esse assunto: "São anjos do diabo/Que chegam no fim da era/Fazendo tanto milagre/Que todo mundo os venera/Saciando fome e sede/São igual ao capa verde/ Correios da Besta-Fera”. Margarida Maria Moura alertou-me para a possibilidade de que o Capa Verde seja a reconstrução mítica e humanizada de algo parecido com o Livro da Capa Verde, em que eram anotados os débitos fiscais dos mineradores no Distrito Diamantino, em Minas Gerais, fonte e motivo de severíssima repressão por parte dos funcionários da Coroa. No Nordeste, no estado da Paraíba, Costa também encontrou o mito do Capa Verde entre trabalhadores do sisal. Nesse caso, porém, eles entendem que o próprio sisal é o Capa Verde (cf. R. Costa, 1991, p. 76-81). Em São Domingos das Latas, no Pará, em 1969, o antropólogo que ali chegou para realizar sua pesquisa foi considerado enviado da Besta (cf. Velho, 1972, p. 130; 1976, p. 237). No pólo ideológico oposto, o mesmo ocorreu com o ativista e líder camponês Manuel da Conceição, no Maranhão, em 1966. Conceição era membro de uma igreja pentecostal. Nessa ocasião, foi especialmente convidado a falar, numa convenção de sua igreja, um pastor vindo de Floriano, no Piauí. O sermão foi contra o "mundo moderno" : "esse mundo moderno estava muito ligado aos comunistas, os capas-verde, correio da besta-fera". Nesse momento, todos começaram a olhar para Manuel da Conceição: "O 'correio' era aquele que estava lá, era eu" (cf. Conceição, 1980, p. 142-143).

${ }^{53}$ Sobre os Tükuna, do Amazonas, cf. Maurício Vinhas de Queiroz (1961). Sobre o movimento messiânico de 1963, entre os Ramkokamekra-Canela, do Maranhão, cf. Eduardo Galvão (1979, p. 281-282) e Manuela Carneiro da Cunha (1973, p. 5-37). Sobre os Krahô, de Goiás, cf. Julio Cezar Melatti (1972). Dentre as várias referências que, sobre o tema, podem ser feitas aos povos Tupi, há o belo estudo de Darcy Ribeiro sobre Uirá, o índio Urubu-kaapor que saiu à procura de Maíra e se matou no rio Pindaré, no Maranhão (cf. Darcy Ribeiro, 1974, p. 13-29).

\section{REFERÊNCIASBIBLOGRÁFICAS}

Almeida, Alfredo Wagner Berno de. (1980) Segurança Nacional e o Revigoramento do Poder Regional. GETAT, Rio de Janeiro, setembro.

. (1989) Terras de preto, terras de santo, terras de índio - uso comum e conflito. In: CAstro, Edna M. Ramos de \& HéBette, Jean (orgs.) Na trilha dos grandes projetos (modernização e conflito na Amazônia). Belém, Cadernos do NAEA, Belém, Universidade Federal do Pará.

Andrade, Maristela. (1981) Gaúchos no sertão. São Luís, Comissão Pastoral da Terra, maio.

Arnaud, Expedito. (1989) O índio e a expansão nacional. Belém, Edições Cejup.

Baldus, Herbert. (1970) Tapirapé - tribo Tupí no Brasil Central. São Paulo, Companhia Editora Nacional/Editora da Universidade de São Paulo.

Bogue, Allan G. (1968) Social theory and the pioneer. In: HofstAdTER, Richard \& LIPSET, Seymour Martin (eds.). Turner and the sociology of the frontier. New York, Basic Books, Inc. Publishers.

BRANDÃo, Carlos Rodrigues. (1978) O divino, o santo e a senhora. Rio de Janeiro, 
Campanha de Defesa do Folclore Brasileiro.

. (1983) Os caipiras de São Paulo. São Paulo, Editora Brasiliense.

BRANFORD, Sue \& Glock, Oriel. (1985) The last frontier (fighting over land in the Amazon). London, Zed Books Ltd.

CABral, Oswaldo Rodrigues. (1979) A campanha do contestado. $2^{\text {a }}$ edição. Florianópolis, Editora Lunardelli.

CAnuto, Antonio. (1975) Maria da Praia. Santa Terezinha (MT), outubro, 12 p. (datilografado), Arquivo da Prelazia de São Félix (MT).

CARDoso, Fernando Henrique. (1979) A fome e a crença (sobre "Os parceiros do rio Bonito"). In: LAFER, Celso et alii. Esboço de figura (homenagem a Antonio Candido). São Paulo, Livraria Duas Cidades.

CAron, Père. (1971) Curé d'indiens. Paris, Union Générale d'Éditions.

CASTAldi, Carlo. (1957) A aparição do demônio no Catulé. In: QueIroz, Maria Isaura Pereira de et alii. Estudos de sociologia e história. São Paulo, Editora Anhambi Limitada.

ConceIção, Manuel da. (1980) Essa terra é nossa (depoimento sobre a vida e as lutas de camponeses no Estado do Maranhão). Petrópolis, Editora Vozes Ltda.

CostA, Francisco de Assis. (1992) Valor e preço, exploração e lucro da produção camponesa na Amazônia: crítica à noção de funcionalidade da produção familiar na fronteira agrícola. In: LÉNA, Philippe \& OlIVEIRA, Adélia Engrácia de (orgs.). Amazônia - a fronteira agrícola 20 anos depois. $2^{\mathrm{a}}$ edição, Belém, Edições Cejup.

Costa, Ramilton Marinho. (1991) O Capa Verde: transformações econômicas e representações ideológicas dos trabalhadores do sisal. In: Vários. Norte e Nordeste - estudos em ciências sociais. Rio de Janeiro, Anpocs/ Inter-American Foundation.

Crocco, Antonio. (1976) Gioacchino da Fiore e il Gioachimismo. Napoli, Liguori Editore.

Cunha, Ayres Câmara. (1974) Além de Mato Grosso. São Paulo, Clube do Livro.

Cunha, Manuela Carneiro da. (1973) Logique du mythe et de l'action (le mouvement messianique canela de 1963). L'Homme - Revue Française d'Anthropologie, tome XIII, numéro 4, Paris-La Haye, Mouton \& Co. Éditeurs, Octobre-Décembre.

DeAn, Warren. Rio Claro (1976) (A Brazilian plantation system, 1820-1920). Stanford, Stanford University Press.

Durhan, Eunice R. (1973) A caminho da cidade (a vida rural e a migração para São Paulo). São Paulo, Editora Perspectiva.

Emmi, Marília Ferreira. (1988) A oligarquia do Tocantins e o domínio dos castanhais. Belém, Centro de Filosofia e Ciências Humanas/NAEA/ UFPA.

FERNANDEs, Florestan. (1968) Sociedade de classes e subdesenvolvimento. Rio de Janeiro, Zahar Editores. 
Ferraz, Iara. (1983) Os Parkatejê das matas do tocantins: a epopéia de um líder Timbira. São Paulo. Dissertação (mestrado). Depto. de Ciências Sociais, FFLCH-USP.

FigueIRA, Ricardo Rezende. (1986) A justiça do lobo (posseiros e padres do Araguaia). Petrópolis, Vozes.

. (1992) Rio Maria (canto da terra). Petrópolis, Vozes.

FOWERAKER, Joe. (1981) The struggle for land (a political economy of the pioneer frontier in Brazil from 1930 to the present day). Cambridge, Cambridge University Press.

- (1982) A luta pela terra (a economia política da fronteira pioneira no Brasil de 1930 aos dias atuais). Trad. Maria Júlia Goldwasser. Rio de janeiro, Zahar Editores.

GALloIs, Dominique Tilkin. (1986) Migração, guerra e comércio: os Waiãpi na Guiana. Revista de Antropologia, São Paulo, n 15. Faculdade de Filosofia, Letras e Ciências Humanas da Universidade de São Paulo.

- (1993) Mairi revisitada - a reintegração da Fortaleza de Macapá na tradição oral dos Waiãpi. São Paulo, Fundação de Amparo à Pesquisa do Estado de São Paulo/Núcleo de História Indígena e do Indigenismo da Universidade de São Paulo.

Galvão, Eduardo. (1976) Santos e visagens (um estudo da vida religiosa de Itá, Baixo Amazonas). 2a edição. São Paulo, Companhia Editora Nacional.

. (1979) Encontro de sociedades - índios e brancos no Brasil. Rio de Janeiro, Paz e Terra.

GERHARD, Dietrich. (1959) The frontier in comparative view. Comparative Studies in Society and History, The Haghe, volume I, number 3, Mouton \& Co. Publishers, March.

GiacCaria, Bartolomeu \& HeIDE, Adalberto. (1972) Xavante (Auwe Uptabi: povo autêntico). São Paulo, Editorial Dom Bosco.

GnaCCARInI, José César A. (1971) Organização do trabalho e da família em grupos marginais rurais do Estado de São Paulo. Revista de Administração de Emprêsas, Rio de Janeiro, vol. 11, nº 1. Fundação Getúlio Vargas, março.

GodFrey, Brian John. (1979) Road to the Xingu: frontier settlement in southern Pará, Brazil. MA thesis. Berkeley, University of California.

Graziano, Eduardo. (1982) As condições de reprodução do campesinato no Vale do Jequitinhonha: o processo de transformação atual. Rio de Janeiro, CPDA/UFRJ.

HÉBETTE, Jean. (1978) Relatório do Seminário sobre a Fronteira Agrícola com Vistas à Resenha da Literatura nos Últimos Anos. Belém (mímeo), agosto.

et alii. (1983) Área de fronteira em conflitos - o leste do médio Tocantins. Belém, Núcleo de Altos Estudos Amazônicos/Universidade Federal 
do Pará (mimeo).

. (s/d.) A resistência dos posseiros no grande Carajás. Belém, Núcleo de Altos Estudos Amazônicos/Universidade Federal do Pará (mímeo).

Hennessy, Alistair. (1978) The frontier in Latin American history. London, Edward Arnold.

IANNI, Octavio. (1978) A luta pela terra (história social da terra e da luta pela terra numa área da Amazônia). Petrópolis, Vozes.

KeLLER, Francisca Isabel Vieira. (1975) O homem da frente de expansão: permanência, mudança e conflito. Revista de História, São Paulo, Vol. LI, n ${ }^{\circ} 102$, ano XXVI. Abril-junho.

KRÄUTLER, Eurico. (1979) Sangue nas Pedras. São Paulo, Edições Paulinas.

LACERDA, Sonia. (1983) Trabalho e posse da terra entre o campesinato de Turmalina. Rio de Janeiro, CPDA/UFRJ.

LAS CASAS, Roberto Décio de. (1964) Índios e brasileiros no vale do rio Tapajós. Boletim do Museu Paraense Emílio Goeldi, (Nova Série), Antropologia, $\mathrm{n}^{\circ}$ 23. Instituto Nacional de Pesquisas da Amazônia, outubro.

LEFEBVRE, Henri. (1949) Problèmes de sociologie rurale - la communauté paysanne et ses problèmes historico-sociologiques. Cahiers Internationaux de Sociologie, Paris, volume VI, quatrième année. Éditions du Seuil.

. (1953) Perspectives de la sociologie rurale. In: Cahiers Internationaux de Sociologie. Paris, volume XIV, huitième année. Éditions du Seuil.

LeOnel, Mauro. (1995) Etnodicéia Uruéu-Au-Au. São Paulo, Editora da Universidade de São Paulo.

LisANSKy, Judith Matilda. (1980) Santa Terezinha: life. In: A Brazilian frontier town. Gainesville. Ph. Thesis, University of Florida, August.

. (1990) Migrants to Amazonia (spontaneous colonization in the Brazilian frontiers). Boulder,Westview Press.

LunA, Regina Celi Miranda Reis. (1984) A Terra era liberta (um estudo da luta dos posseiros pela terra no Vale do Pindaré-MA). Natal, Universidade Federal do Rio Grande do Norte.

MARTins, Edilson. (1978) Nossos índios, nossos mortos. Rio de Janeiro, Editora Codecri.

Martins, José de Souza. (1969a) Modernização agrária e industrialização no Brasil. América Latina, Rio de Janeiro, ano 12, nº 2. Centro Latinoamericano de Pesquisas em Ciências Sociais, abril-junho.

. (1969b) Modernização e problema agrário no Estado de São Paulo. Revista do Instituto de Estudos Brasileiros. São Paulo, $\mathrm{n}^{\circ} 6$, Universidade de São Paulo.

. (1975) Capitalismo e tradicionalismo (estudos sobre as contradições da sociedade agrária no Brasil). São Paulo, Livraria Pioneira Editora.

. (1981) Introdução crítica à sociologia rural. São Paulo, Editora Hucitec. 
. (1983) Os camponeses e a política no Brasil. 2a edição. Petrópolis, Editora Vozes.

. (1986) A reforma agrária e os limites da democracia na "Nova República”. São Paulo, Editora Hucitec.

. (1993) Antropofagia e barroco na cultura latino-americana. In:

A chegada do estranho. São Paulo, Editora Hucitec.

. (1995) A reprodução do capital na frente pioneira e o renascimento da escravidão no Brasil. Tempo Social (Revista de Sociologia da USP), São Paulo, vol. 6, nos 1-2: 1-25. Universidade de São Paulo, Faculdade de Filosofia, Letras e Ciências Humanas, Departamento de Sociologia, junho.

MARX, Carlos. (1959) El capital - crítica de la economía política. Tomo III. Trad. Wenceslao Roces. México, Fondo de Cultura Económica.

Melatti, Julio Cezar. (1972) O messianismo Krahô. São Paulo, Herder/Edusp.

Menezes, Paulo Roberto Arruda de. (1995) A questão do herói-sujeito em cabra marcado para morrer, filme de Eduardo Coutinho. Tempo Social (Revista de Sociologia da USP), São Paulo,volume 6, n ${ }^{\text {os }} 1$ 1-2: 107126. Universidade de São Paulo, Faculdade de Filosofia, Letras e Ciências Humanas, Departamento de Sociologia, junho.

Mindlin, Betty. (1985) Nós, Paiter - Os Suruí de Rondônia. Petrópolis, EditoraVozes.

Monbeig, Pierre. (1940) Ensaios de Geografia Humana Brasileira. São Paulo, Livraria Martins.

. (1952) Pionniers et planteurs de São Paulo. Paris, Librairie Armand Colin.

. (1957) Novos Estudos de Geografia Humana Brasileira. São Paulo, Difusão Européia do Livro.

Monteiro, Duglas Teixeira. (1974) Os errantes do novo século. São Paulo, Livraria Duas Cidades.

Moreira Neto, Carlos de Araújo. (1959) Relatório sobre a situação atual dos índios Kayapó. Revista de Antropologia, São Paulo, volume 7, $\mathrm{n}^{\text {os }} 1$ 2, Universidade de São Paulo, Faculdade de Filosofia, Letras e Ciências Humanas, Departamento de Ciências Sociais, Universidade de São Paulo, junho-dezembro.

Moura, Margarida Maria. (1988) Os deserdados da terra (a lógica costumeira e judicial dos processos de expulsão e invasão da terra camponesa no sertão de Minas Gerais). Rio de Janeiro, Bertrand Brasil.

Mussolini, Gioconda. (1955) Persistência e mudança em sociedades de 'folk' no Brasil. In: FernANDES, Florestan (org.). Symposium etno-sociológico sobre comunidades humanas no Brasil. São Paulo, Separata dos Anais do XXXI Congresso Internacional de Americanistas.

Musumeci, Leonarda. (1988) O mito da terra liberta (colonização 'espontânea', campesinato e patronagem na Amazônia Oriental). Anpocs/Vértice. 
São Paulo, Editora Revista dos Tribunais.

NeIva, Arthur Hehl. (1949) A imigração na política brasileira de povoamento. Revista Brasileira de Municípios, ano II, nº 6, abril-junho, p. 226. Apud WaIBEL, Leo H. (1955) As zonas pioneiras do Brasil. Revista Brasileira de Geografia, ano XVII, n ${ }^{\circ} 4$. Outubro-dezembro.

OliveIrA, Roberto Cardoso de. (1964) O Índio e o mundo dos brancos (a situação dos Tukúna do Alto Solimões). São Paulo, Difusão Européia do Livro. . (1967) Problemas e hipóteses relativos à fricção interétnica: sugestões para uma metodologia. Revista do Instituto de Ciências Sociais, Rio de Janeiro, volume IV, $\mathrm{n}^{\circ} 1$. Universidade Federal do Rio de Janeiro.

. (1976) Do Índio ao Bugre (O processo de assimilação dos Terêna). $2^{\mathrm{a}}$ edição. Rio de Janeiro, Livraria Francisco Alves Editora S.A.

Pereira, Pablo. (1995a) Sertanista contata índios isolados em RO. O Estado de S. Paulo, 6/09, p. A15.

. (1995b) Funai encontra novo grupo de índios em RO. O Estado de $S$. Paulo, 25/10, p. A14.

PivetTA, Darci Luiz. (1993) Iranxe: luta pelo território expropriado. Cuiabá, UFMT/Editora Universitária.

Posey, Darrel A. (1982) Time, space, and the interface of divergente cultures: the Kayapó indians of the Amazon face the future. Revista de Antropologia, São Paulo, volume 25. Universidade de São Paulo, Faculdade de Filosofia, Letras e Ciências Humanas, Departamento de Ciências Sociais, FFLCH-USP.

QueIRoz, Maria Isaura Pereira de. (1957) La "guerre sainte" au Brésil: le mouvement messianique du "contestado". Boletim, São Paulo, n 187. Faculdade de Filosofia, Ciências e Letras da Universidade de São Paulo.

QueIroz, Maurício Vinhas de. (1961) Contribuição ao estudo do messianismo Tukúna. Comunicação apresentada na V Reunião Brasileira de Antropologia, Belo Horizonte. Apud Oliveira (1964).

(1966) Messianismo e conflito social (a guerra sertaneja do Contestado, 1912-1916). Rio de Janeiro, Editora Civilização Brasileira S.A.

REY, Pierre-Philippe. (1976) Les alliances de classes. Paris, François Maspero.

RIBEIRo, Darcy. (1974) Uirá vai ao encontro de Maíra. In: - Uirá sai à procura de Deus (ensaios de etnologia e indigenismo). Rio de Janeiro, Paz e Terra.

. (1977) Os índios e a civilização (a integração das populações indígenas no Brasil moderno). $2^{\mathrm{a}}$ edição. Petrópolis, Editora Vozes.

SARTre, Jean-Paul. (1966) Questão de método. Trad. de Bento Prado Júnior. São Paulo, Difusão Européia do Livro.

Schmink, Marianne \& Wood, Charles H. (1989) Contested frontiers in Amazonia. Gainesville, Center for Latin American Studies, University of Florida, August. 
. (1992) Contested Frontiers in Amazonia. New York, Columbia University Press.

Silva, Aracy Lopes da. (1986) Nomes e amigos: da prática Xavante a uma reflexão sobre os Jê. São Paulo, Faculdade de Filosofia, Letras e Ciências Humanas da Universidade de São Paulo.

Steinberg, Jonathan.(1981) In St. Joachim's republic. Society, $\mathrm{n}^{\circ} 28$. May.

Todorov, Tzvetan. (1984) La conquista dell'America (il problema dell'Altro). Trad. Aldo Serafini. Torino, Giulio Einaudi Editore.

TourAIne, Alain. (1961) Industrialisation et conscience ouvrière à São Paulo. Sociologie du Travail, Paris, troisième année, $n^{\circ}$ 4/61. Éditions du Seuil.

TURNER, Frederick Jackson. (1956) The significance of the frontier in American history, In: TAYLOR, George Rogers (ed.). The turner thesis concerning the role of the frontier in American history. Boston, D. C. Heath and Company.

Velho, Otávio Guilherme. (1976) Capitalismo autoritário e campesinato. São Paulo/Rio de Janeiro, Difel.

. (1967) Análise preliminar de uma frente de expansão da sociedade brasileira. Revista do Instituto de Ciências Sociais, Rio de Janeiro, volume IV, $\mathrm{n}^{\circ} 1$. Universidade do Rio de Janeiro.

. (1972) Frentes de expansão e estrutura agrária. Rio e Janeiro, Zahar Editores.

VIDAL, Lux. (1977) Morte e vida de uma sociedade indígena brasileira (os Kayapó-Xikrin do rio Cateté). São Paulo, Editora Hucitec/Editora da Universidade de São Paulo.

VIEIRA, António. (1994) Apologia das coisas profetizadas. Trad. do latim de Arnaldo Espírito Santo. Organização e fixação do texto de Adma Fadul Muhana. Lisboa, Edições Cotovia.

VIEIRA, Maria Antonieta da Costa. (1981) Caçando o destino (um estudo sobre a luta de resistência dos posseiros do Sul do Pará). São Paulo. Dissertação (mestrado). Antropologia. Pontifícia Universidade Católica de São Paulo.

VIERTLER, Renate B. (1990) A vaca louca: tendências do processo de mudança sócio-cultural entre os Bororo-MT. Revista de Antropologia, São Paulo, volume 33. Depto. de Antropologia, FFLCH-USP.

WAGLEY, Charles. (1977) Welcome of tears (the Tapirapé indians of central Brazil). New York, Oxford University Press. 